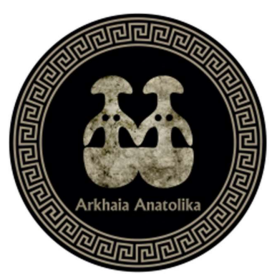

Arkhaia Anatolika

Anadolu Arkeolojisi Araştırmaları Dergisi

The Journal of Anatolian Archaeological Studies

Volume 4 (2021)

\title{
Karatay Medresesi Çini Eserler Müzesinden Ünik Özellikte İki Siren/Harpi Figürlü Seramik
}

\author{
Two Unique Siren/Harpy Figured Ceramics in the Karatay Madrasah \\ Tile Works Museum
}

Yurdagül ÖZDEMİR

(D) https:/ / orcid.org/0000-0002-0594-4655

Geliş Tarihi: 12.02.2021 | Kabul Tarihi: 12.03.2021 | Online Yayın Tarihi: 18.03.2021

Makale Künyesi: Özdemir, Y. (2021). Karatay Medresesi Çini Eserler Müzesinden Ünik Özellikte İki Siren/Harpi Figürlü Seramik. Arkhaia Anatolika, 4, 123-140. DOI: 10.32949/ Arkhaia.2021.29
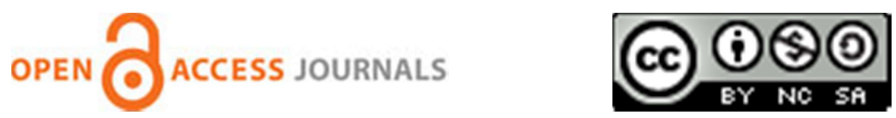

Arkhaia Anatolika, Anadolu Arkeolojisi Araştırmaları Dergisi "Açık Erişimli" (Open Access) bir dergidir. Kullanıcılar, dergide yayınlanan makalelerin tamamını tam metin olarak okuyabilir, indirebilir, makalelerin çıktısını alabilir ve kaynak göstermek suretiyle bilimsel çalışmalarında bu makalelerden faydalanabilir. Bunun için yayıncıdan ve yazar(lar)dan izin almasına gerek yoktur.

Dergide yayınlanan makalelerin bilimsel ve hukuki sorumluluğu tamamen yazar(lar)ına aittir.

Arkhaia Anatolika, The Journal of Anatolian Archaeological Studies follows Open Access as a publishing model. This model provides immediate, worldwide, barrier-free access to the full text of research articles without requiring a subscription to the articles published in this journal. Published material is freely available to all interested online readers.

The scientific and legal propriety of the articles published in the journal belongs exclusively to the author(s). 


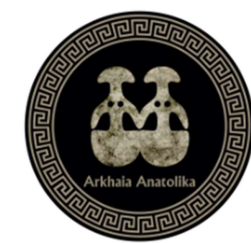

ISSN: 2651-4664

Arkhaia Anatolika

arkhaiaanatolika.org

Arkhaia Anatolika 4 (2021) 123-140

DOI: 10.32949/Arkhaia.2021.29

Araştırma Makalesi / Research Article

\title{
Karatay Medresesi Çini Eserler Müzesinden Ünik Özellikte İki Siren/Harpi Figürlü Seramik
}

\author{
Two Unique Siren/Harpy Figured Ceramics in the Karatay Madrasah Tile Works \\ Museum
}

\author{
Yurdagül ÖZDEMİR*
}

\begin{abstract}
Öz
Çalışmamızın konusunu Konya Karatay Medresesi Çini Eserler Müzesi'nde bulunan, siren/harpi tasvirli kırık durumdaki iki seramik eserin tanıtılması ve bu eserlerin Orta Çă̆ Anadolusu fantastik figürlü eserler arasındaki özel durumunun belirlenmesi oluşturmaktadır. Anadolu'da Malazgirt Savaşı'ndan sonraki süreçte Bizans ve Anadolu Selçuklu Devletleri arasında gelişen siyasi, askeri, sosyal-ekonomik ilişkiler, kültürel ve sanatsal bir etkileşim ortamı doğurmuştur. Bu durum, üslup farklılıkları olmakla birlikte iki kültürün hakim olduğu ortak coğrafyada, birlikte yaşam pratiklerinin geliştirilmesiyle ortak beğeniye hitap eden sanat eserlerinin üretilmesine olanak sağlamış, bununla ilişkili olarak zamanla oluşan ortak bir görsel repertuvar, her iki kültürün sanat eserlerinde benzer motiflerin kullanımını yaygınlaştırmıştır. Siren/harpi, sfenks ve melekler gibi koruyucu, tılsımlı güçleri olduğuna inanılan fantastik yaratıklar sanatsal etkileşim unsurlarını yansıtan örnekler olarak karşımıza çıkmaktadır. Anadolu'da Bizans ve Anadolu Selçuklu sanatında, mimari süsleme, seramik ve çini gibi farklı türde eserlerde örnekleri bulunan siren/harpi tasvirleri, her iki kültürde de güçlü, kuvvetli, kötülüklerden koruyucu fantastik yaratıklar olarak canlandırılmıştır. Bizans sanatında tasvir edilen bazı siren/harpi figürleri Anadolu Selçuklu sanatı etkisinde değerlendirilmektedir. Bu etki, çoğu zaman eserlerin üretiminde çalışan Rum veya Türk ustaların, her iki kültürün tasvir geleneğini de iyi bilmesinden kaynaklanmaktadır. Çalışmamızda incelediğimiz siren/harpi figürlü eserler, Anadolu'da çok kültürlü bir coğrafyada oluşan ortak bir görsel repertuvardan yararlanılarak üretilen, Bizans-Selçuklu sanatsal etkileşimini günümüze taşıyan maddi kanıtlar olarak önem taşımaktadır.
\end{abstract}

Anahtar Kelimeler: Bizans, Siren, Harpi, Fantastik Yaratık, Selçuklu, Sanatsal Etkileşim

\begin{abstract}
Making two broken ceramic works with siren/harpy depictions in Konya Karatay Madrasah Tile Works Museum known and determining the special status of these artworks among the medieval Anatolian fantastic figures are the subjects of this study. The political, military, social-economic relations that developed between the Byzantine and Anatolian Seljuk States in the period after the Battle of Malazgirt in Anatolia created an environment of cultural and artistic interaction. This situation, with the development of culture of living together has given chance to produce artworks that appeal to common taste, despite the differences in style, in the geography that is dominated by two cultures. A common visual repertoire formed in this way in the course of time has spread the use of similar motifs in the artworks of both cultures. Fantastic creatures such as siren/harpy, sphinx and angels believed to have protective and magical powers are regarded as examples that reflect the

\footnotetext{
* Dr. Yurdagül Özdemir, Selçuk Üniversitesi, Edebiyat Fakültesi, Sanat Tarihi Bölümü, Konya/TR. E-mail: yurdagulozdemir@selcuk.edu.tr. / Orcid iD: 0000-0002-0594-4655 Bu çalışma Selçuk Üniversitesi Sosyal Bilimler Enstitüsü’nde 2020 yılında, Prof. Dr. Ali Baş danışmalığında tamamlanan "Anadolu'da Bizans-Selçuklu Kültürel Etkileşiminin Sanata Yansımaları" başlıklı doktora tezinden geliştirilerek hazırlanmıştır. Öncelikle, çalışmanın her aşamasında yardımlarını ve desteğini esirmeyen danışmanım Prof. Dr. Ali Baş'a teşekkürlerimi sunarım. Konya Arkeoloji Müzesi, Karatay Medresesi Çini Eserler Müzesi ile İnce Minare Taş ve Ahşap Eserler Müzesi'nde çalışmama izin veren Konya Müzeler Müdürlüğü yetkilerine ve çalışmalarımdaki yardımlarından dolayı müze uzmanlarından Mehmet Ali Çelebi, Sevgi Gürdal ve Mustafa Burak Ermiş'e çok teşekkür ederim.
} 
elements of artistic interaction. The siren/harpy depictions, which have examples in different types of artwork such as architectural decoration, ceramics and tiles in Byzantine and Anatolian Seljuk art in Anatolia, have been portrayed as fantastic creatures that protect against strong evil in both cultures. Some siren/harpy figures depicted in Byzantine art are evaluated under the influence of Anatolian Seljuk art. This is mostly due to the fact that Greek or Turkish masters working on the production of the works know well the depiction traditions of both cultures. The works with siren/harpy figures, which we have examined in our study, are important as material evidences that carry the Byzantine-Seljuk artistic interaction to the present day, produced by using a common visual repertoire formed in a multicultural geography in Anatolia.

Keywords: Byzantine, Siren, Harpy, Fantastic Creature, Seljuk, Artistic Interaction

\section{Giriş}

1071 yilında Sultan Alparslan ve İmparator Romanos Diogenes komutasındaki Büyük Selçuklu ve Bizans ordusu arasında gerçekleşen Malazgirt Savaşı, Selçukluların galibiyetiyle sonuçlanmıştır ${ }^{1}$. Malazgirt Savaşı Anadolu tarihinin en önemli olaylarından biridir. Savaş sonrasında Anadolu'ya başlayan yoğun Türk göçleri ve burada Büyük Selçuklu Devleti'nin bir kolu olarak Anadolu Selçuklu Devleti'nin kurulması, Orta Çă̆ Anadolusu'nun siyasi, demografik, sosyal-kültürel ve sanatsal ortamında önemli değişikliklere neden olmuştur. Bu süreçte öncelikli olarak askeri, siyasi ve politik ilişkiler kuran Bizans ve Selçuklu Devletleri arasında zamanla kültürel ve sanatsal bir etkileşim ortamı da oluşmuştur.

Malazgirt Savaşı'nı takip eden yıllarda Türkler Anadolu'ya yerleşmeye başlamış ve bu göçler 14. yüzyıla kadar aralıklarla devam etmiştir. Gelenler arasında çoğunluğu Oğuz Türkleri oluşturmakla birlikte, Kıpçaklar, Karluklar, Halaçlar ve hatta Uygurların da bulunduğu bu Türkler, başta Maveraünnehir olmak üzere Harizm, Horasan, Azerbeycan ve İran bölgesinden Anadolu'ya göçmüşlerdir². Bu göç hareketi ve yerleşme süreci ile birlikte 1176 yılında Bizans güçlerine karşı kazanılan Miryokefalon Savaşı, Türklerin Anadolu topraklarına kalıcı olarak yerleşmelerini mümkün kılmıştır³.

Selçuklu Türkleri, Anadolu'nun fethiyle birlikte yalnızca kendilerine yerleşmek için yeni bir yurt edinmemişler, Anadolu'yu çoğunlukla Müslüman olan İran ve Orta Asya coğrafyasından gelen insanların fikirlerine de açmışlardır. Buna bağlı olarak Roma, Bizans, Gürcü ve Ermeni gibi Anadolu'nun kendilerinden önceki uygarlıklarıyla tanışarak, yeni bir kültürel ve doğal ortam yaratmışlardır. Başlangıçta, yeni gelenler ve yerliler arasında kültür, yaşam biçimi ve dini farklılıklar nedeniyle bir uyumsuzluk süreci yaşansa da zamanla her iki topluluğun uyum içinde yaşadığ1 koşullar oluşmuştur. Lilie'ye göre "12. yüzyıl Bizans ile Selçuklu Devletleri arasında bir ortak birliktelik dönemi gibi görünmektedir, bu barış sınır çatışmalarının hatta büyük seferlerin eksik olmadığı bir barıştır. Buradaki en önemli husus her iki tarafin bir diğerinin varlığın kabul etmesidir" 4 . Bu ortak yaşam süreci, beraberinde kültür alışverişini getirmiş ve bu alışveriş de sanatsal etkileşime kaynak oluşturmuştur.

Bilindiği gibi uygarlıkların sanat ürünleri dönemin kültürel ortamını yansıtırlar. Anadolu'da bu süreçte görülen kültürel çeşitlilik sanat eserlerinde de izlenebilmektedir. Özellikle figürlü süslemede benzer ikonografik temaların, motiflerin kullanımı dikkat çeker. Her iki kültürün eserlerinde görülen siren/harpi, sfenks, çift başl1-tek gövdeli yaratıklar ve melekler gibi koruyucu, tılsımlı güçleri olduğuna inanılan fantastik figürler, karşılıklı olarak sanatsal etkileşim unsurlarını yansıtan örneklerdir. Bu fantastik figürler, "birden fazla figürün

\footnotetext{
1 Yinanç 1934, 38; Sevim 1993, 223; Dirimtekin 1993, 247; Ostrogorsky 1999, 318-319; Urfalı Mateos 2000, 143; Bryennios 2008, 54 .

2 Ocak 1991, 111.

3 Savvídĩs 1981, 45; Khoniates 1995, 123-133; Ostrogorsky 1999, 361.

4 Lilie 2005, 199.
} 
doğaya aykırı biçimde tek bir figür olarak verildiği anormal görünümlü kombinasyonlar" 5 olarak tanımlanır. Orta Çağ' da Anadolu'da Bizans ve Anadolu Selçuklu sanatında hem mimari hem de küçük el sanatlarında örnekleri bulunan siren ${ }^{6} /$ harpi $^{7}$ figürü kuş gövdeli, kadın başlı olarak tasvir edilmektedir. Siren/harpiler, her iki kültürde de güçlü, kuvvetli, koruyucu fantastik yaratıklar olarak canlandırılmışlardır.

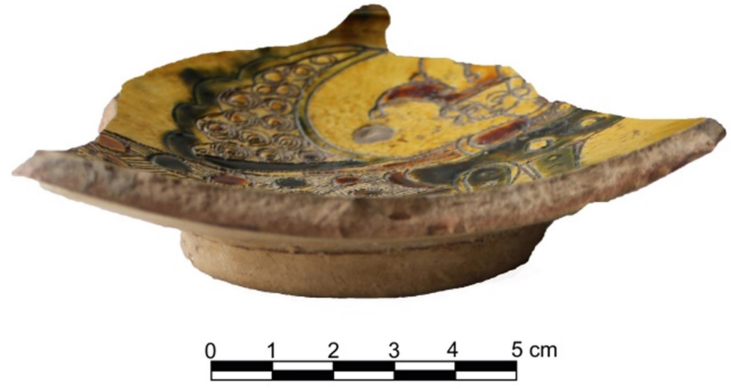

Figür 1a: Karatay Medresesi Çini Eserler Müzesi, siren/harpi tasvirli kase (env. no. 1254)

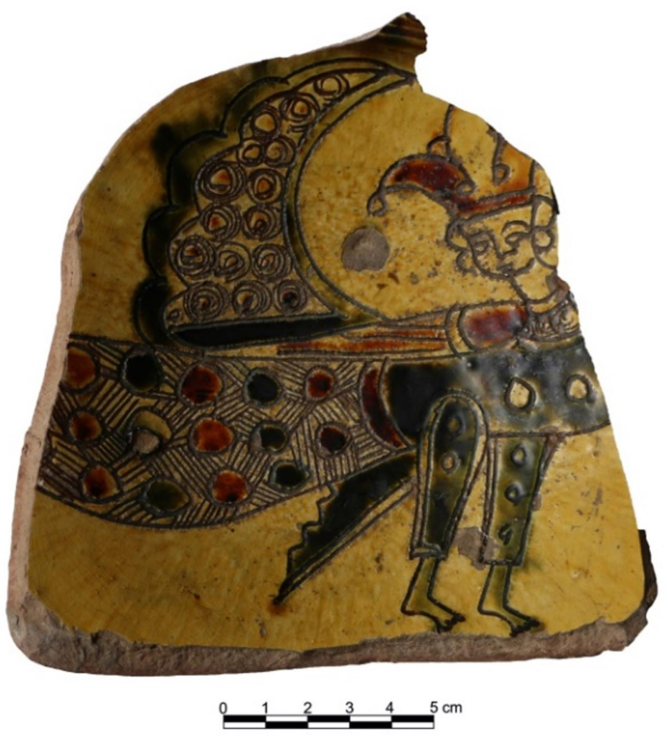

Figür 1c: Siren/harpi tasvirli kasenin iç yüzeyi

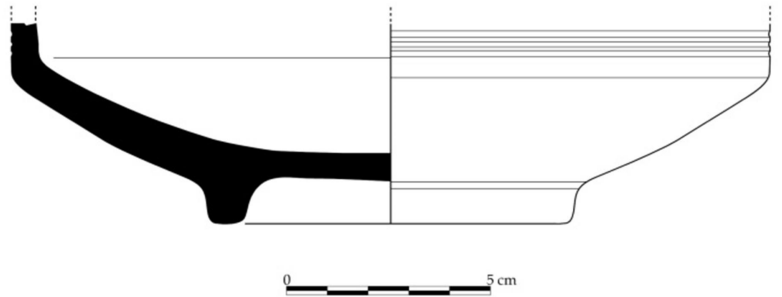

Figür 1b: Siren/harpi tasvirli kasenin çizimi

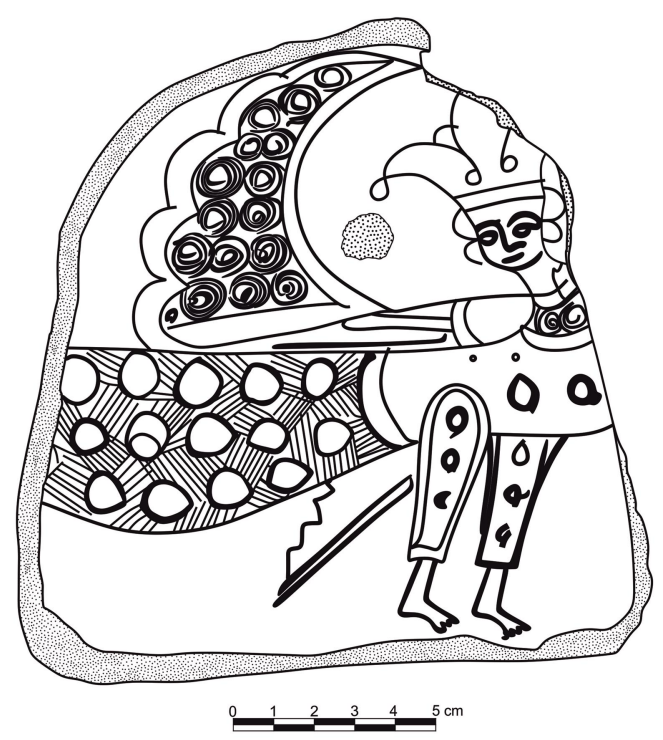

Figür 1d: Kasenin iç yüzeyinin çizimi

\footnotetext{
${ }^{5}$ Doğer 2004, 79.

${ }^{6}$ Yunan ve Roma mitolojisinde Siren (Seirenler veya Seirenes) yarı kadın yarı kuş deniz daimonlarıdır. Sirenlerin adı ilk defa Odysseia'da geçer. Burada sayıları ikidir. Daha sonraki tradisyonlarda sayıları üç ya da dörttür. Mitograflar tradisyonel olarak bunların değerli birer müzisyen olduklarını söylerler (Grimal 1997, 726-727). M. Önder, Türk mitolojisinde yarı insan yarı hayvan şeklinde esatirî yaratıklar arasında Zümrüd-ü Anka adı verilen Siren veya Simurg' un da olduğunu belirtir. Simurg Farsça bir kelime olup, 'otuz kuş' anlamına gelmektedir. Siren kelimesinin de Farsça 'otuz renk' anlamina gelen 'sireng' kelimesinden geldiği düşünülmektedir. Simurg' un gövdesi güvercin, doğan, akbaba gibi iri bir kuş olarak resmedilirken, baş kısmı ise dolgun yüzlü, başında tacı olan güzel bir kadın olarak tasvir edilmektedir. Bu fantastik yaratık, Türk masalları ve efsanelerinde Simurg (Zümrüd-ü Anka) adıyla geçer. Anka, uzun boyunlu boynunda bir gerdanlık bulunan, çok yükseklerden uçan bir kuş olarak düşünülmüş ve çok yükseklerden uçan Hüma (Devlet Kuşu) ile Zümrüd-ü Anka'nın çoğu zaman aynı kuş olduğu sanılmıştır (Önder 1967b, 6-7). Siren figürü son zamanlarda Türk sanatı ile ilgili olarak yapılan araştırmalarda Türk mitolojisindeki "Umay" ile ilişkilendirilmektedir.

7 Yunan ve Roma mitolojisinde 'Harpi'ler (Harpyialar veya Harpyiai) Tahumas ile Okeanos kızı Elektra'nın kızları kanatlı cinler olarak tanımlanır. Olympos öncesi tanrılar kuşağında yer alırlar. Kanatlı kadınlar ya da kadın başlı kuşlar şeklinde temsil edilirler. Keskin pençeleri vardır. Sayıları genellikle ikidir, bazen üç olarak da bilinir. Kasırga (Aello), Hızlı Uçan (Okypete) ve Karanlık (Kelaino) ismindeki harpiler çocukları ve ruhları kaçırırlar (Grimal 1997, 229). Yunanca 'kapmak, çalmak' anlamına gelen 'harpi' kelimesi ile ilişkili olarak bu fantastik yaratıklar, can alan hayvanlar olarak da düşünülmüşlerdir (Impelluso 2004, 359).
} 


\section{Envanter Numaralı Eser}

Konya Karatay Medresesi Çini Eserler Müzesi'nde 1254 envanter numarasıyla kayıtlı, kırık durumdaki kasenin dip kısminda (tondo) yer alan siren/harpi figürü, Orta Çă̆ seramikleri içerisinde üslup açısından ünik bir örnektir (fig. 1a-d). Alçak halka kaideli (Ç.: 9 $\mathrm{cm}, Y .: 1,1 \mathrm{~cm})$, geniş gövdeli kasenin iç yüzeyi sarı renkte sırlanmış, dışı ve kaidesi sırsız bırakılmıştır. Ölçülebilen genişliği 14,8 cm, yüksekliği 5,1 cm ve cidar kalınlığ1 0,8 cm olan kasenin hamuru açık kremit kırmızısı renktedir (fig. 1a-b). Çok renkli sgraffito (polychrome sgraffito) $^{8}$ tekniğindeki eserde desenler kahverengi ve yeşil renkte boyanmıştır (fig. 1c-d).

Yüzü cepheden, gövdesi profilden verilen siren/harpi figürü, kulak hizasında kıvrımlı saçlar, oval yüzde iri badem gözler, kaş hattı ile birleşen küçük burun ve küçük ağızlı olarak verilmiştir. Başında sivri tepelikli üç dilimli taç bulunmaktadır. İnce, uzun boyunda süslü bir yaka detayı yer alır. Siren/harpi tasvirinin kuyruğu, tavus kuşu şeklinde dairesel ve çizgisel olarak verilen ayrıntılarıyla dikkat çeker. Sırttan çıkarak yukarıya doğru kavisli devam eden ve uç kısmı sivri sonlanan süsleme, ikinci bir kanat olarak düzenlenmiştir. Bu kanatta, birbiri içine dolanan spiraller kazıma çizgilerle verilmiş, kuyrukta ise dairesel motiflerin içleri yeşil ve kahverengi renkte boyanarak, tavus kuşlarının kuyruklarındaki göz detaylarına benzer bir desen oluşturulmuştur. Bu desenlerin çevresine ise yatay ve dikey şekilde paralel çizgiler eklenerek, tüy detayları verilmiştir. Sağ kanat yukarıda ve çizgisel ayrıntılarla belirtilerek kahverengiye boyanmış, sol kanat ise aşağıya doğru sarkıtılarak verilmiş ve yeşil renkte boyanmıştır. Siren/harpinin yeşil renkte boyanan bacakları ile ayakları kuş gibi değil, insan ayağı şeklinde tasvir edilmiş, bacaklara dairesel bezemeler yapılmıştır. Figürün başı ile yukarıya uzanan kanadı arasında, bacakları arasında ve kuyruk üzerinde üçayak izi mevcuttur.

Anadolu Selçuklu sanatında taş, alçı, çini gibi çeşitli malzemelerde görülen siren/harpi tasvirli eserlerin çini sanatında sayıca en fazla örneği Kubadabad Sarayı'nda bulunmaktadır9. Kubadabad Büyük ve Küçük Saray yıldız çinilerindeki sirenler, komposizyon şeması açısından birbirine benzerler. Genellikle ortada yer alan siren/harpi figürlerinin şişkin göğüslü gövdeleri profilden, başı ise cepheden resmedilmiştir. Kuyrukları aşağıya veya yukarıya uzananlar olduğu gibi bazılarının kuyrukları, volütlerle biten kıvrımlar şeklinde düzenlenmiştir ${ }^{10}$.

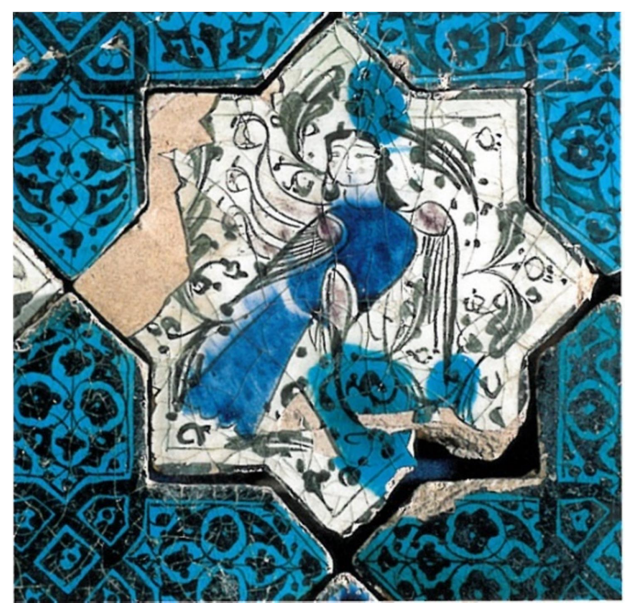

Figür 2: Kubadabad Sarayı siren tasvirli çini

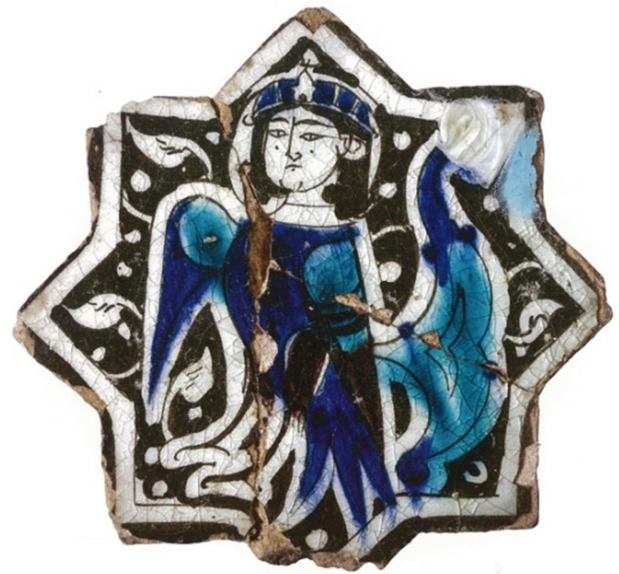

Figür 3: Kubadabad Sarayı siren tasvirli çini (Karatay Medresesi Çini Eserler Müzesi)

8 Teknik, bazı araştırmacılar tarafından “boyalı kazıma” (Acara-Eser 2020, 144; Özkul-Fındık 2001, 92-98; 119-120) olarak da adlandırılmaktadır.

9 Arık 2000, 120-124, fig. 156-161.

10 Arık 2000, 120; Arık 2007, 312. 
Karatay Medresesi Çini Eserler Müzesi 1254 envanter numaralı eserdeki siren/harpi figürü ile kompozisyonun yerleştirilişi, yüz tipi ve kanatların verilişi açısından yakın örnekler Kubadabad Sarayı çinilerinde görülmektedir. Kubadabad Sarayı buluntusu sekiz kollu yıldız formunda, şeffaf sır altına kobalt mavi, siyah ve patlıcan moru renkte boyanmış çininin merkezinde siren/harpi figürü yer almaktadır (fig. 2). Sağa dönük olarak, başı cepheden, gövdesi $3 / 4$ profilden verilen figür, oval yüzlü, bitişik yay kaşlı, çekik gözlü ve küçük ağızlı olarak tasvir edilmiştir. Figürün ortadan ikiye ayrılmış düz saçları enseye kadar uzanmaktadır. Sağ kanat kapalı, sol kanat hafif açık ve aşağıya doğru sarkmıştır. Figürün sırtından çıkarak, yukarıya doğru kavisli devam eden yaprak şeklindeki süsleme dikkat çekmektedir. Kuyruğu uzun ve dilimli verilen figürün sağ ayağı yere basar şekilde iken, sol ayağı belirsizdir. Kubadabad Sarayı buluntusu sıraltı tekniğindeki sekiz kollu yıldız çinideki bir diğer siren/harpi figürünün başı cepheden, gövdesi $3 / 4$ profilden verilmiştir (fig. 3). Başında palmet motifli bir başlık bulunan figür, oval yüzlü, badem gözlü, burun hattı ile birleşen yay kaşlı ve küçük ağızlı olarak betimlenmiştir. Saçlar enseye kadar uzanmakta ve boyunda beyaz bir yaka bulunmaktadır. Sirenin öne doğru uzanan sağ kanadı açık şekilde, sol kanadı ise kapalı olarak verilmiştir. Sırtta ikinci bir kanat şeklinde düzenlenmiş rumi motifi görülmektedir.

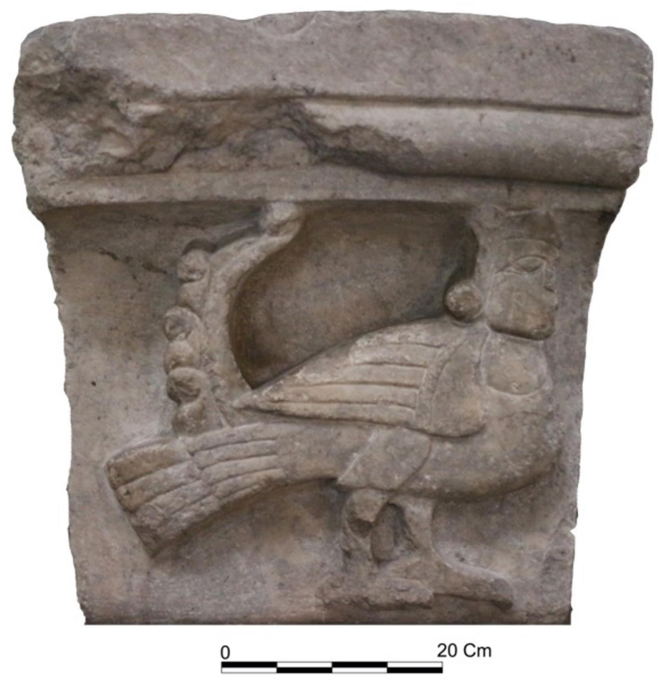

Figür 4: Siren tasvirli taş eser (İnce Minare Taş ve Ahşap Eserler Müzesi)

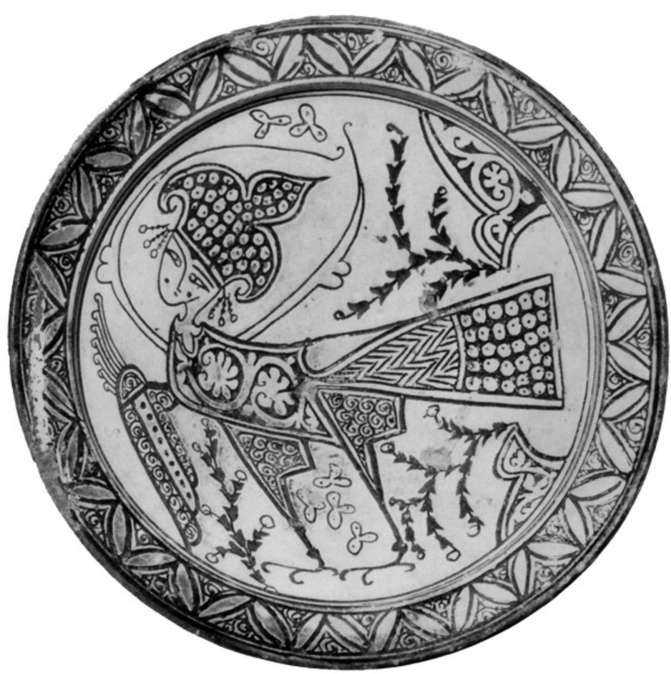

Figür 5: Siren/harpi tasvirli tabak (Dumbarton Oaks Koleksiyonu, env. no: D.O.58.103)

Karatay Medresesi Çini Eserler Müzesi'ndeki siren/harpi tasviri ile sırttan çıan ikinci kanadın varlığı bakımından benzer bir diğer örnek, Konya Kalesi'nde bulunan, İnce Minare Taş ve Ahşap Eserler Müzesi'nde sergilenen, 886 envanter numaralı siren/harpi figürlü levhadır (fig. 4). Bir kemere ait (kilit taşı) olduğu düşünülen ${ }^{11} 56 \times 60 \mathrm{~cm}$ ölçülerindeki eserin cephesine yüksek kabartma tekniğinde siren/harpi figürü işlenmiş, blok üstte dışbükey kavisli bir profil ile sonlandırılmıştır. Gövdesi, başı ve ayakları profilden verilen siren/harpi figürü ensesine kadar uzanan kıvrımlı saçlar, iri badem gözler, küçük burun ve küçük ağız ile betimlenmiştir. Kanat ayrıntıları çizgisel olarak verilen figürün gövdesinden yukarıya doğru uzanarak, volüt şeklinde sonlanan ikinci bir kanadı bulunur. Ayaklar ve pençeler kabaca işlenmiştir.

1254 numaralı eserdeki siren/harpi tasviri ile üç dilimli taç, gövdesi ve kuyruğunun tavus kuşu şeklinde verilmesi gibi özellikleriyle benzer, Bizans Dönemi siren/harpi tasviri Dumbarton Oaks Koleksiyonundaki D.O.58.103 envanter numaralı tabakta bulunmaktadır

11 Erdemir 2009, 46. 
(fig. 5). Alçak halka kaideli sgraffito tekniğindeki çukur tabağın (Ç.: 31,7 cm, Y.: 8,5 cm) iç yüzeyine siren/harpi figürü tasvir edilmiş, koyu yeşil renkte surlı dış yüzey ise spiral motiflerle bezenmiştir. D. T. Rice figürün, üç dilimli tacı ve kanatlı verilişi gibi özellikleriyle İan sanatı etkisinde olduğunu vurgular ve süsleme özellikleri bakımından eserin 13. yüzyılda (1250 civarında), Chersonese'de üretilmiş olabileceğini önerir ${ }^{12}$.

Anadolu'da, üç dilimli başlık ve yüz tipi bakımindan Dumbarton Oaks Koleksiyonunda bulunan eserdeki siren/harpi figürüyle benzer bir örnek, Divriği Kale Kazısı'nda bulunan, boyalı

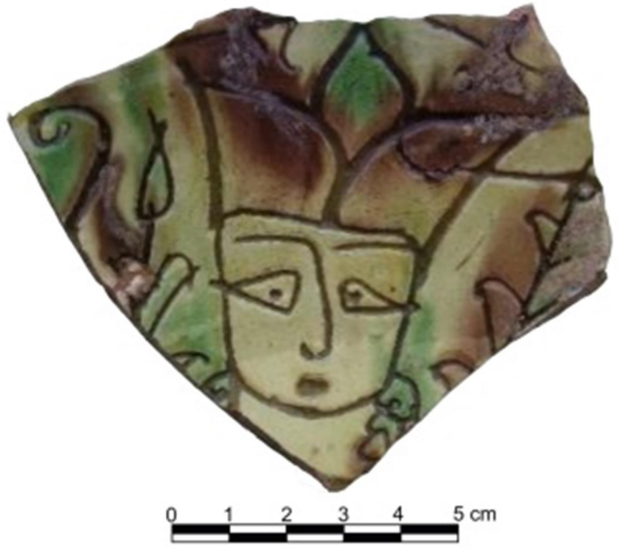

Figür 6: Divriği Kale kazısında bulunan seramik parçası

kazıma tekniğinde işlenmiş seramik parçasındaki insan tasviridir ${ }^{13}$ (fig. 6). Figür, üç dilimli başlıklı, oval yüzlü, gözleri üçgen şeklinde, burun hattı ile birleşen düz kaşlı ve küçük ağızlı olarak tasvir edilmiştir. Figürün iki yanında bitkisel komposizyon bulunmaktadır. Eser, ithal seramikler arasında yer almaktadır. M. Acara-Eser'e göre "Figür üç dilimli başlı̆̆l ile benzerleri geç Bizans dönemine tarihlenen ve genellikle Hatay ve Çukurova bölgesi üretimi olan seramiklerde"14 görülen harpi figürlerine teknik ve üslup açısından benzerlik göstermektedir"15.

1254 envanter numaralı eserdeki siren/harpi tasviriyle, üslup açısından ilişkilendirilebilecek fantastik kurgulu bir diğer örnek, İnce Minare Taş ve Ahşap Eserler Müzesi'ndeki 893 envanter numaralı mermer levhada bulunmaktadır (fig. 7a-c). $86 \mathrm{~cm}$ yüksekliğinde, korunan genişliği yaklaşık $60 \mathrm{~cm}$ olan levhanın ön yüzünde, üç dilimli şeritlerle birbirine bağlanan dairesel madalyonlardan oluşan antrolaklı simetrik düzenleme vardır. Levhanın her iki kössesi de kırık durumdadır. Üst sırada yer alan iki antrolakın içerisinde birer sfenks, alttaki iki antrolak içerisinde ise geyik tasvirleri yer alır (fig. 7a-c). Eser, genel geometrik tasarım özellikleri açısından Bizans sanatı özelliklerini taşırken, sfenkslerin farklı üslubu açısından Selçuklu Dönemi özelliklerini yansıtmaktadır.

Müze kayıtlarında satın alma yoluyla müzeye geldiği belirtilen korkuluk levhasının buluntu yeri Konya Rum Kilisesi olarak belirtilmiştir. Sfenkslerin başında üç dilimli taçlar yer alırken, kuyrukları ejder başı şeklinde sonlanmaktadır (fig. 7c). Orta Bizans Dönemi levhalarında yaygın olarak kullanılan tasarım içerisine yerleştirilen İslam sanatı özellikleri gösteren bu sfenksler V. M. Tekinalp'e göre, “Orta Çă̆g'da özellikle Konya çevresinde Selçuklu

\footnotetext{
12 Rice 1966, 210-211, 217, fig. 1-2.

13 Acara-Eser 2020, 144, şek. 10b.

14 Hatay ve Çukurova Bölgesi'nin yerel üretimi olan "Saint Simeon Limanı”, “Al-Mina” veya "Haçlı Dönemi Seramiği" adıyla tanınan eserlerin çoğunluğu kazıma ve renkli sır akıtma tekniğinde bezenmiş kaplardan oluşmaktadır. Bölgedeki çeşitli merkezlerde bulunan 12. yüzyılın ortaları 13. yüzyılın ilk yarısı arasında üretilmiş seramiklerde, Türk-İslam sanatı etkilerinin daha belirgin olduğu görülmektedir. Hatay-Çukurava bölgesi üretimlerinde, figürler ve formlarda Türk-İslam sanatı etkileri daha güçlüdür. Bu eserlerin sadece Hristiyan alıcılar için üretilmediği, Müslüman ve farklı dinlere inanan alıcılara da hitap eder şekilde tasarlandıkları düşünülmektedir (Köroğlu 2007, 441-452). Port Saint Symeon kazılarında 'saki' figürlü bir kase bulunmuş ve bu eserin benzerleri daha sonraki yıllarda Adana, Misis, Tarsus, Dörtyol Kinet Höyük kazılarında da ele geçmiştir. S. Redford, türbanları, tirazlı kaftanları ve oturuş şekilleriyle bu figürlerin "şark" kültürlerini temsil ediyor olabileceğini, saki figürlerinin "hem elit saray mensubu olarak hem de yiyecek içecek getiren olarak sınıf üstünlüğünün ve bolluğun simgesi olduğunu" vurgular. Ayrıca Port Saint Symeon seramiklerini Haçlı seramiği olarak nitelendirmenin yanlış olduğunu, bu seramiklerin bütün Doğu Akdeniz toplumlarının görsel kültürünün ve ticaretinin ayrılmaz bir parçası olduğunu belirtir (Redford 2001, 486-488).

15 Acara-Eser 2020, 144, şek. 10b. Üç dilimli başlık ve figürün göz-kaş yapısı ile benzer bir örnek, Ahlat'ta bulunmuştur. Bk. Karamağaralı 2007, 145, fig. 22a.
} 
sanatı etkisinde gelişen bir Bizans Sanatı örneğgi"16 olmaları açısından önemlidir. Y. Demiriz ise "Levhanın arka yüzü Bizans ${ }^{17}$ ön yüzü Selçuk işidir" sözleriyle, eserin her iki kültürle ilişkili olduğunu vurgulamıştır. Ayrıca yazar, levhanın her iki yüzünün de Konya'nın Selçuklu Dönemi yönetiminde, 13. yüzyılda bir Bizans Kilisesi için yapıldığını düşünmektedir ${ }^{18}$. Y. Erdemir ise daha erken tarihli olan eserin ön yüzünün Selçuklular Dönemi'nde yeniden kompoze edilerek, son şeklini almış olabileceğinin kuvvetle muhtemel olduğunu belirtir ${ }^{19}$. Sonuç olarak, Orta Çağ' da Selçuklu başkentindeki bir kilise için tasarlanan litürjik eserdeki sfenks figürlerinde, Anadolu Selçuklu figür geleneğinin izlenmesi, dönemin sanatsal ortamını yansıtması açısından önem kazanmaktadır.

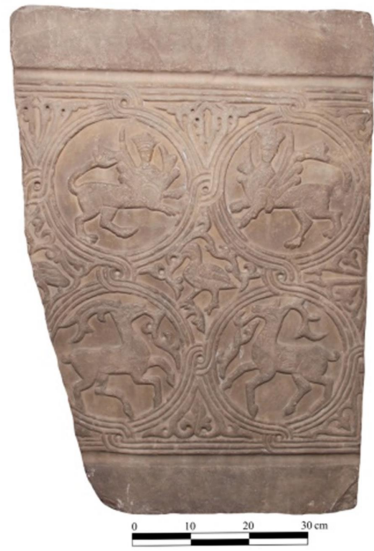

Figür 7a-b: Kabartmalı mermer levhanın ön ve arka cephesi (İnce Minare Taş ve Ahşap Eserler Müzesi, env. no. 893)

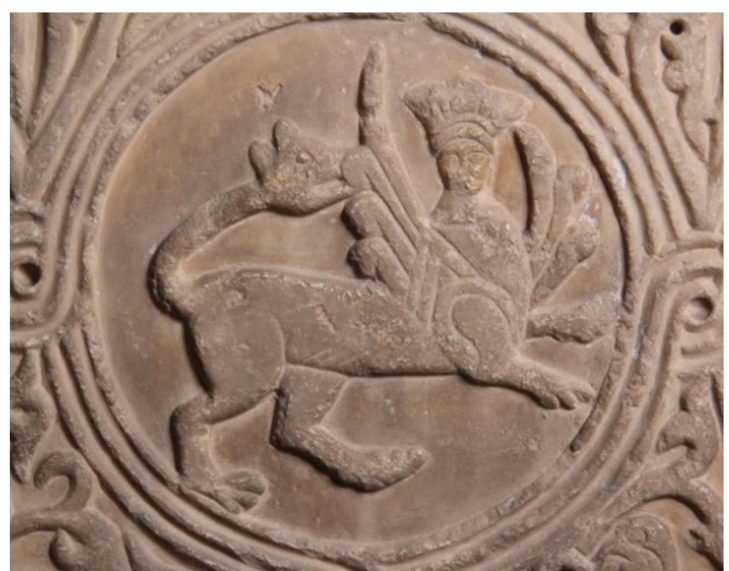

Figür 7c: Kabartmalı mermer levhada soldaki sfenks figürü

Karatay Medresesi Çini Eserler Müzesi 1254 envanter numaralı eser ile benzer şekilde, sırttan çıkan ikinci bir kanat ile tasvir edilen hayvan betimleri arasında tavus kuşları da vardır. Bunlardan ilki, 2017 yılında Divriği Kalesi'nde yapılan çalışmalarda ${ }^{20}$ Mağara Bölgesi'nde bulunan bir kaidedir. 5,4 cm çapında, iç yüzeyi boyalı kazıma tekniğindeki kaide, yeşil renkte sırlanmıştır (fig. 8). Başı kısmen korunan tavus kuşu uzun boyunlu tasvir edilmiş, sol kanadı kapalı iken, sağ kanadı yukarıya doğru kıvrılan paralel çizgilerle belirtilmiştir. Kuyruğun ucunda ise olasılıkla tüyleri temsil eden kıvrım çizgiler kısmen belirgin olarak verilmiştir. Eser, 13. yüzyıl Bizans tavus kuşu tasvirlerinden farklı olması nedeniyle 13. yüzyılın ilk yarısına tarihlenen bir Selçuklu eseri olarak tanımlanmıştır21. Divriği Kalesi'nde bulunan tavus kuşu betimi, boynunun uzun, kanadının sivrilerek

16 Tekinalp 2006, 111.

17 Eserin arka yüzünde büyük bir haç ve kırık durumdaki köşesinde sadece bir kolu görülen diğer bir haç kabartması yer alır. Haçların her biri dikdörtgen bir çerçeve içerisine alınmıştır. Tamamı görülen haçın sağında ve solunda, tek kolu görülen haçın ise sağ kolunun altında profilden görülen bir tavus kuşu tasviri yer almaktadır. Haçların her biri Golgota Tepesi'ni sembolize eden dört basamaklı bir piramit üzerine oturtulmuştur (Demiriz 1970, 222). Benzer kompozisyondaki örnekler, Uşak Müzesi'nde, ortada bir haç ve iki yanında tavus kuşu tasvirleri bulunan lahit kapağı üzerinde (Parman 2002, 159; lev. 84, fig. 102a); Konya Koyunoğlu Müzesi'ndeki 13 envanter numaralı taş eserde (Kunduracı ve Mimiroğlu 2011, fig. 16); Konya Arkeoloji Müzesi'nde bulunan, Çumra Alibeyhöyügü̈'ndeki kilise kalıntısından getirilen zemin mozaiğinde (Mimiroğlu 2006, 145, fig. 8), 198 ve 1980.12.1 envanter numaralı eserlerde; Afyonkarahisar Arkeoloji Müzesi'nde (env. no. 1394, 1433-34 ve 1500); Seyitgazi Arkeoloji Müzesi'nde (env. no. A.856/85); Uşak Arkeoloji Müzesi'nde (env. no. 13.1.94) ve Eskişehir Arkeoloji Müzesi'nde (env. no. 102.80 ve 18.80) bulunmaktadır (Kunduracı ve Mimiroğlu 2011).

18 Demiriz 1970, 221, 229-230.

19 Erdemir 2009, 56.

20 Divriği Kale kazısı seramik buluntularının son verilerine göre özellikle 12. yüzyıldan itibaren bölgede hakimiyet kuran Mengücekoğulları ile birlikte Divriği'de sırlı seramik üretiminin söz konusu olduğu, üretimin 13. ve 14. yüzy1llarda da devam ettiği düşünülmektedir (Acara-Eser 2020, 151).

21 Acara-Eser 2019, 45. 
yukarıya doğru uzanması ve kuyruğunun biçimi bakımından 1254 envanter numaralı siren/harpi figürü ile benzerdir. Bir diğer benzer örnek, Kubadabad Sarayı kazılarında bulunan bir çinideki tavus kuşu tasviridir. Sıraltı tekniğinde işlenmiş, sekiz köşeli yıldız formundaki bu çininin merkezinde yer alan tavus kuşu, Selçuklu sanatı tavus kuşu tasvirlerinin en güzel örneklerinden biridir (fig. 9). Tavus kuşunun yukarıya kıvrılan kanadı, açık mavi üzerine koyu mavi yatay çizgilerle doldurulmuştur.
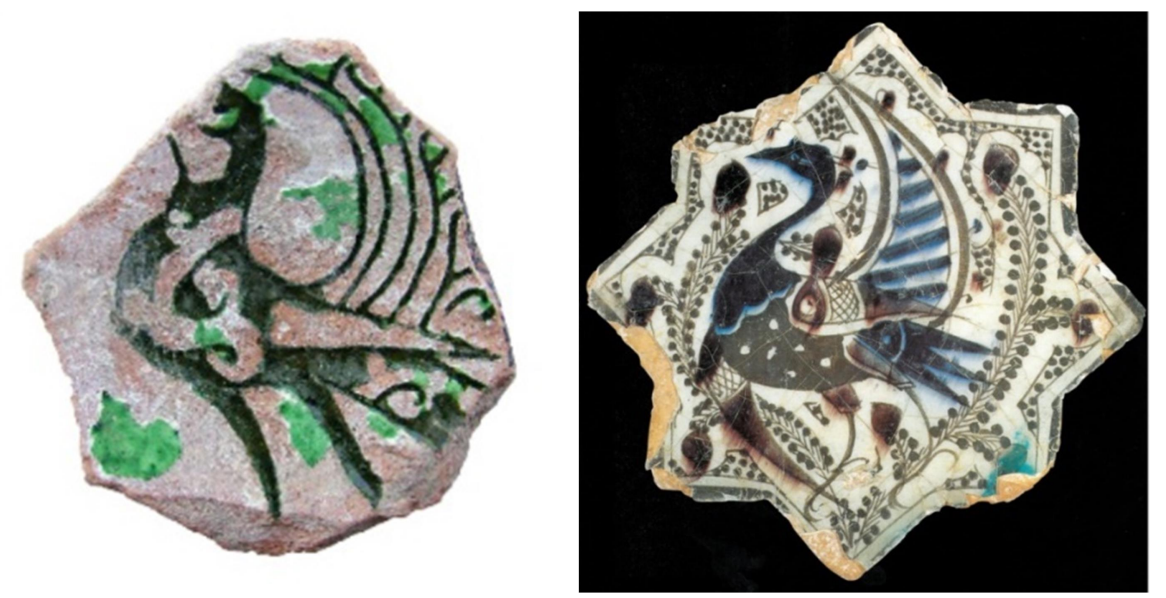

Figür 8: Divriği Kalesi'nde bulunan tavus kuşu bezemeli seramik parçası

Figür 9: Kubadabad Küçük Saray'da bulunan tavus kuşu tasvirli çini

\section{Envanter Numaral1 Eser}

Karatay Medresesi Çini Eserler Müzesi'nde bulunan siren/harpi figürlü diğer ünik örnek, 3676 envanter numaralı eserdir. Figür, Konya'da 2013 yılında yapılan Selçuk Otel hafriyatı kazısında bulunan bir kasenin dip kısmında (tondo) yer alır (fig. 10a-d). Alçak halka kaideli (Ç.: 7,7 cm, Y.: 2,1 cm), ölçülebilir genişliği 14,2 cm, yüksekliği 4,8 cm, cidar kalınlığ1 $0,7 \mathrm{~cm}$ olan eser, çok renkli sgraffito (polychrome sgraffito) tekniğindedir. Açık kiremit renkte hamur yapısına sahip eserde desenler, krem renk astar üzerine kahverengi ve yeşil renkte boyanmış ve kap açık sarı renkte sırlanmıştır (fig. 10a-b).

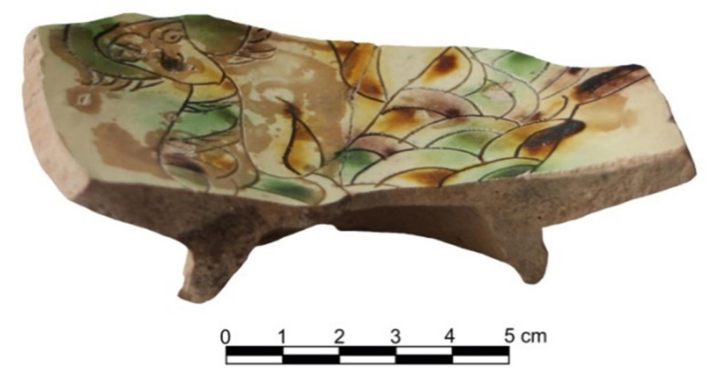

Figür 10a: Karatay Medresesi Çini Eserler Müzesi siren/harpi tasvirli kase parçası (env. no. 3676)

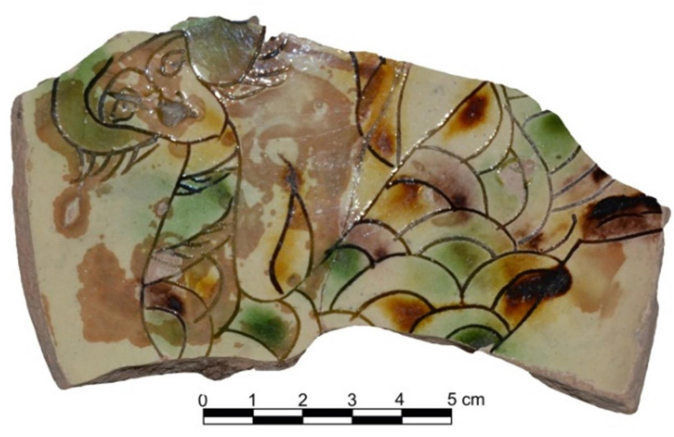

Figür 10c: Kase parçasının iç yüzeyi

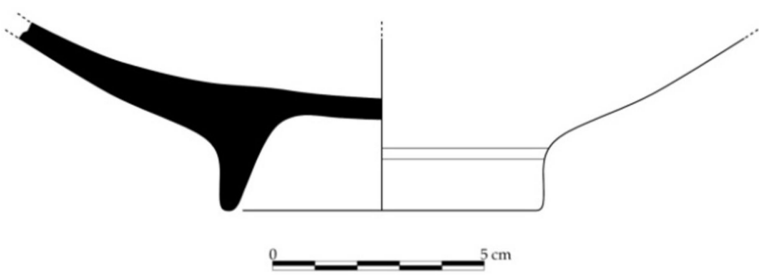

Figür 10b: Siren/harpi tasvirli kase parçasının çizimi

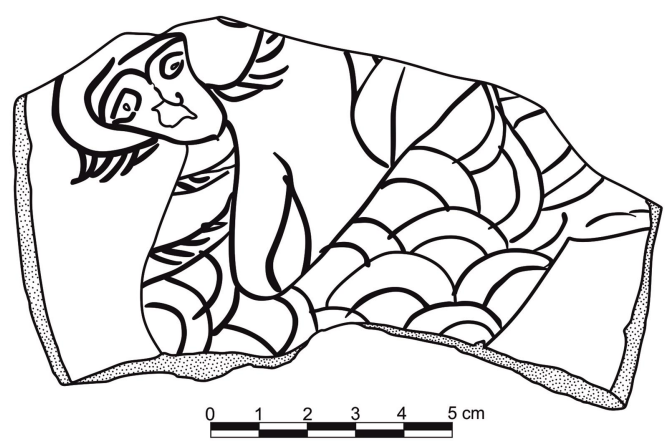

Figür 10d: Kase parçasının iç yüzeyinin çizimi 
Oval yüzde düğme şeklinde gözler, burun hattı ile birleşen kaşların betimlenmesi ile eser aceleci bir üslupta, acemi bir elden çıkmış izlenimi vermektedir (fig. 10c-d). Figürün ensesinde sonlanan saçlarının uç kısmı dikey çizgilerle belirtilmiştir. Vücut ve başın yerleştirilişine göre uzun ve orantisiz bir boyun kismina sahip siren/harpi figürünün ayak ve kuyruk kısmı kırık durumdadır. Gövdesi yarım daire şeklinde kazıma çizgilerle hareketlendirilmiş, yeşil ve kahverengiye boyanmıştır. Boyunda spiral şeklinde, başa doğru dolanarak uzanan bir süsleme görülür. Sırtından çıkan kanatlar da basit çizgilerle belirtilmiştir. Renkler büyük oranda dağılmış, sır tahrip olmuş durumdadır. Siren/harpi tasvirinin gövdesi, boyun

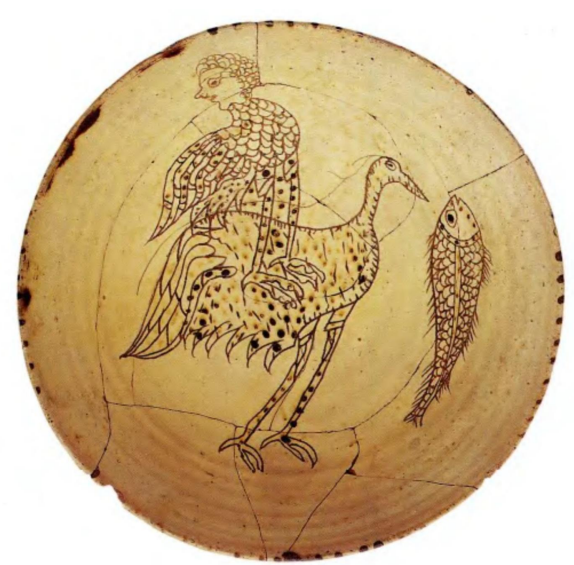

Figür 11: Su kuşu üzerinde siren/harpi ve balık tasvirli kase (Korinth Arkeoloji Müzesi, env. no. C-1931-005) ve başın veriliş tarzı açısından Selçuklu figür geleneğini yansıtır. Ancak figür, göz, kaş, burun gibi yüzdeki ayrıntılarla Bizans insan figürleri tarzında verilmiştir.

Siren/harpi figürleri İslam sanatında olduğu gibi Hristiyan sanatında da güçlü, kuvvetli ve koruyucu fantastik yaratıklar olarak canlandırılmışlardır. Bizans sanatında en fazla taninan ve kullanilan antropoid (insan hayvan kombinasyonu) fantastik betimlemeler arasında sirenler/harpiler de yer alır ${ }^{22}$. Siren/harpi tasvirleri 12. yüzyıldan itibaren heykellerde, 13. ve 14. yüzyılda ise seramiklerde görülmektedir ${ }^{23}$. Seramik eserlerde siren/harpi figürlü örnekler az sayıdadır. Ancak bu eserler ünik kompozisyonları ile dikkat

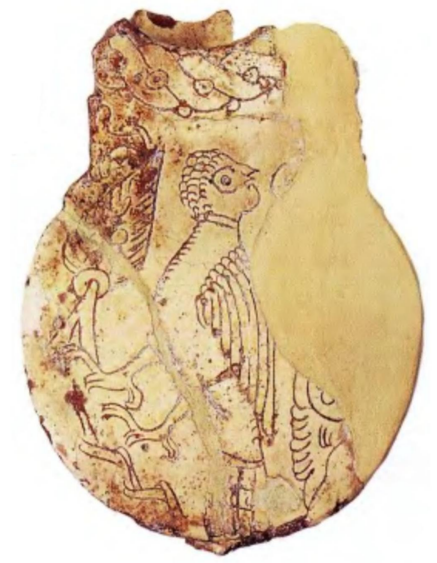

Figür 12: Siren/harpi tasvirli buhurdan (Atina Bizans ve Hristiyan Eserleri Müzesi, env. no. T 125/BM 1676) çekicidirler ${ }^{24}$. Siren/harpi figürlerinin görüldüğü örnekler arasında, 12. yüzyıla tarihlenen Korinthos buluntusu kırmızı benek boyal1 bir kase ${ }^{25}$ (fig. 11); Atina Bizans ve Hristiyan Eserleri Müzesi'nde bulunan, 12. yüzyıla tarihlendirilmiş sgraffito seramik buhurdan ${ }^{26}$ (fig. 12); Dumbarton Oaks Koleksiyonunda bulunan eserlerden, 13. yüzyıla tarihlendirilmiş sgraffito tekniğindeki bir masa amphorast27; 10.11. yüzyıllara ait kutu kapağ ${ }^{28}$ ile 13. yüzyıla tarihlenen D.O.58.103 numaralı seramik tabak ${ }^{29}$ (fig. 5); D. T. Rice'ın özel kolleksiyonundaki bir eser (fig. 13) ve Leningrad Hermitage Müzesi'nde bulunan Chersonese' den getirilmiş bir sürahi ${ }^{30}$ yer almaktadir.

Korinthos buluntusu C-1931-005 envanter numaralı alçak halka kaideli, küresel gövdeli kase (Ç.: 20,6 cm), 1140-

\footnotetext{
22 Doğer 2004, 79.

23 Rice 1966, 210.

24 Doğer 2004, 83.

25 Morgan 1942, 94, fig. 70; Papanikola-Bakirtzi 1999, 169, kat. 196; Evans ve Wixom 1997, 267, kat. 189; Doğer 2004, 84, fig. 8 .

26 Papanikola-Bakirtzi 1999, 30, kat. 8; Doğer 2004, 84, fig. 7.

27 Yeşil ve kahverengi sırla zenginleştirilen masa amphorası siren/harpi figürü ile birlikte tek boynuzlu, çakal suratlı aslan ve kuşların öyküsel çizimlerini içeren bantlar taşır. L. Doğer'e göre eser, "İslam el yazmalarındaki hayvan hikayelerinin konu ve resimsel anlatımından etkilenmiş bezemesi ile çok zengin bir örnek sunar" (Doğer 2004, 84).

28 Doğer 2004, 84, dn. 8.

${ }^{29}$ Rice 1966, 210-211, 217, fig. 1-2.

30 Öney 1971, 98, fig. 28-29.
} 
1170 yıllarına tarihlenmektedir ${ }^{31}$. Kazıma tekniğindeki eserin merkezinde uzun bacaklı, uzun sivri gagalı, sağa doğru dönük olarak verilen su kuşu figürünün üzerinde siren/harpi figürü yer alır (fig. 11). Gövdesi sağa, başı geriye dönük olarak verilen siren/harpi figürü büyük gözlü, sivri burunlu ve kısa dalgalı saçlı olarak tasvir edilmiştir. Uzun bacaklı, büyük pençeli olan figürün gövdesi benekler ve çizgisel süslemelerle bezenmiştir.

Atina Bizans ve Hristiyan Eserleri Müzesi'nde T 125/BM 1676 envanter numarası ile kayıtlı olan eserin geliş yeri bilinmemektedir (fig. 12). 12. yüzyıla tarihlendirilen, sgraffito tekniğindeki 15,6×12,8 cm ölçülerindeki seramik buhurdan ${ }^{32}$, yeşilimsi sarı renkte sırlanmıştır. Sola doğru dönük biçimde verilen siren/harpi figürü, büyük gözlü, uzun sivri burunlu ve kısa saçlı olarak tasvir edilmiştir. Kanat içleri ince paralel çizgilerle taranan, pençeleri belirgin olarak verilen figür sol tarafta, ucunda bir yaprakla sonlanan kıvrık dallar üzerinde durur şekilde resmedilmiştir. Atina Bizans ve Hristiyan Eserleri Müzesi'ndeki buhurdan ile Korinthos buluntusu kase üzerindeki siren/harpi tasvirleri, başlarının arkaya dönük olarak verilişi, büyük gözlü, uzun sivri burunlu, saçların dalgalı ve kısa olarak işlenişi gibi benzer özelliklere sahiptir. Siren/harpi figürleri saç ve yüz tipi, uzun bacakları, büyük güçlü pençeleri, saçların, kanatların, tüylerin benekler ve çizgisel ayrıntılarla verilmesi gibi özelliklerle Bizans Dönemi siren/harpi tasvirlerinin genel özelliklerini yansıtmaktadırlar.

Bizans sanatında görülen siren/harpi figürlerinden bazılarının tamamen Anadolu Selçuklu stilinde tasvir edildiği belirtilmektedir. D. T. Rice'ın özel kolleksiyonundaki siren/harpi betimli fragman ile Leningrad Hermitage Müzesi'nde Chersonese'den getirilmiş sürahi üzerindeki çift siren/harpiler bu örnekler arasında yer alır ${ }^{33}$. Rice'ın özel kolleksiyonundaki Bizans Dönemi'ne tarihlenen eserdeki figür oval yüzlü, iri çekik gözlü, kalın kaşlı betimlenmiş ve göz altlarındaki çizgiler, burun hattıyla birleşik olarak verilmiştir (fig. 13). Figürün ense hizasında çizgisel detaylarla verilen saçları ve saçların ucundan başlayarak yukarıya doğru uzanan kurdele şeklindeki bezeme dikkat çeker. Siren/harpi figürü sağ bacağını öne doğru uzatmış, sağ kanadı kapalı, sol kanadı açık olarak betimlenmiştir. Selçuklu sanatı etkisinde değerlendirebileceğimiz siren/harpi tasvirinin üslup açısından yakın örnekleri Konya Kılıçaslan Köşkü alçı kabartmasında görülmektedir (fig. 14). 13. yüzyıla tarihlenen alçı kabartmada, birbirine sırt sırta dönük iki siren/harpi figürü betimlenmiştir. Bu figürlerden soldakinin gövde ve yüzü tahrip olmuş, sağdaki ise daha iyi durumda korunmuştur. Alçı kabartmadaki figürler, başın, gövdenin, kanatların ve kuyruğun veriliş biçimi açısından Rice'ın koleksiyonundaki Bizans Dönemi siren/harpi figürüyle oldukça paralel özellikler gösterirler ${ }^{34}$.

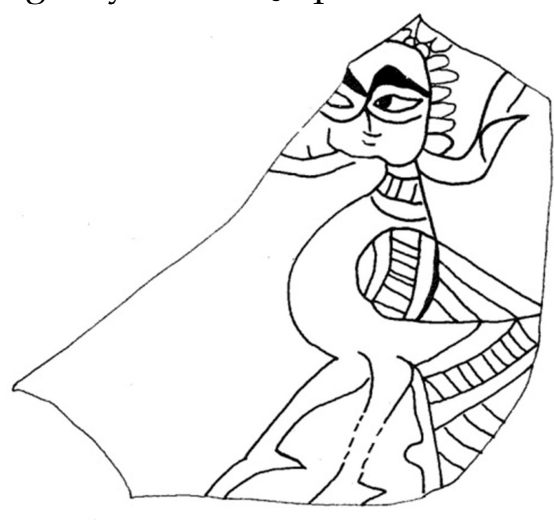

31 Papanikola-Bakirtzi 1999, 169, kat. 196.

32 Papanikola-Bakırtzı 1999, 30, kat. 8.

33 Öney 1971, 98, fig. 28-29.

34 İran Selçuklu seramiklerinde de benzer üslupta siren tasvirleri bulunmaktadır. Bk. Baer 1965, lev. VIII, 13-14; IX,15; XXXIX,68; XL,69.
Figür 13: D. T. Rice'ın özel koleksiyonunda bulunan siren/harpi figürlü fragman

Figür 14: Konya Kılıçaslan Köşkü'nde bulunan, siren figürlü alçı kabartma (Türk ve İslam Eserleri Müzesi, env. no. 2340-5) 
Anadolu'da Bizans ve Selçuklu birlikteliğinin yaşandığg1 13. yüzyıl tasvirlerinde, ortak bir sanatsal çevrenin ürünü olarak değerlendirilen unsurlar, Kubadabad Sarayı'ndaki bir başka siren/harpi tasvirinin ayrıntılarında görülmektedir (fig. 15a-b). Karatay Medresesi Çini Eserler Müzesi'nde bulunan sekiz köşeli yıldız çinide tasvir edilen bu figür, yüz tipi ile sarayın diğer sekiz kollu yıldız çinilerinde, karakteristik Türk tipinde verilen siren/harpi figürlerinden ayrılmaktadır. Söz konusu figür, kaş ve burnun verilişi bakımından Karatay Müzesi 3676 envanter numaralı eserle benzer özellikler taşır.

Kubadabad Küçük Saray'da bulunan, sıraltı tekniğinde yapılmış sekiz köşeli yıldız biçimdeki çinide desenler siyah, kobalt mavi ve patlıcan moru renkte boyanmıştır. Dışta iki siyah çizgi ile sınırlandırılan kompozisyonun merkezinde siren/harpi figürü verilmiş, çevresindeki alanlar ise hiç boşluk bırakılmaksızın stilize bitki motifleri ve beneklerle doldurulmuştur. Figürün gövdesi cepheden, başı ise $3 / 4$ profilden işlenmiştir. Oval yüzlü, çekik gözlü, kalın birleşik yay kaşlı, kaş hattı ile birleşen uzun çekme burunlu ve küçük ağızlı betimlenen figürün çene hizasında biten saçları, ortadan ikiye

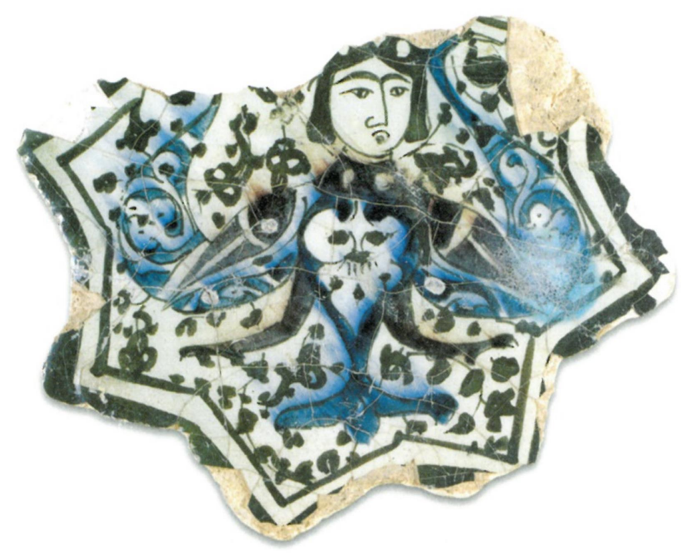

Figür 15a: Kubadabad Küçük Saray'da bulunan siren tasvirli çini ayrılmıştır. Figür, burun şekli ve kaş yapısıyla Kubadabad Sarayı'nda bulunan diğer siren/harpi tasvirlerinden farklılık gösterir. Arma gibi cepheden görünen figür, küçük bir kuş gövdesine sahiptir. Sırtından ikişer kanat çıkmaktadır. Bu kanatlardan öndekiler daha küçük, arkadakiler ise daha görkemli bir şekilde yukarıya uzanmaktadır. Gövdesinin ortasında büyük bir palmet motifi yer alır. Gövdesi patlıcan moru renkte boyanmış, göğsündeki palmet motifi ise rezerv tekniğinde yapılmıştır. Arka kanatlarda da palmetli bitkisel desenler mevcuttur. R. Arık, siren figürü ile ilgili "Bu sirenin yüzü diğerlerindeki Asyalı tiplere benzememektedir. Yine minyatür üslubunda ve badem gözlü olmakla birlikte bu tek kaşl çekme burunlu çehrede daha Anadolu yerlisi bir ifade göze çarpmaktadır"35 sözleriyle eserin Anadolu Selçuklu örneklerinden farklılığını vurgulamıştır.

Büyük Selçuklu geleneğini sürdüren Anadolu Selçuklu insan tasvirlerinde, yuvarlak yüzler, belirgin elmacık kemikler ve dolgun yanaklar, yay şeklinde bitişik kaşlar, hafif çekik gözler, genelde düz bazen ise hafif çıkıntılı tasvir edilen burun, genellikle tek yatay çentik ile işaretlenen küçük ağız ve yuvarlak çene, karakteristik özelliklerdir. Alaaddin Tepesi'nde bulunan ve Karatay Medresesi Çini Eserler Müzesi'nde korunan barbutin tekniğindeki insan başı, karakteristik Selçuklu tipini göstermesi açısından önemli bir örnektir (fig. 16). Figür, iri badem gözleri, kaşlarla birleşen yassı burnu, küçük ağz1 ${ }^{36}$ ve üç dilimli başlığı ile klasik Türk tipindedir. Kubadabad çinisindeki, daha çok Anadolu yerlisi tipinde olan siren/harpinin benzer örneği ise Kapadokya'da I. İzzeddin Keykavus Dönemi'ne tarihlenen Suveş (Şahinefendi) Sebastoslu Kırk Martir Kilisesi'nin (1216-1217) tonozlarında yer alan figürlerden birinde görülmektedir (fig. 17). Tekinalp, tonozdaki bu figür ile ilgili olarak “ $B u$

\footnotetext{
35 Arlk 2000, 123.

36 Orta Asya Türk topluluklarından Osmanlı çinilerine kadar neredeyse hiç değişmeden kalan yüz tipinde, çekik gözler, düz hafif çıkıntılı burun ve küçük ağız karakteristik özelliklerdir. 13. yüzyıl Anadolu figürlerinde bu karakteristik özellikler Kubadabad Sarayı sıraltı ve lüster tekniğindeki çinilerdeki insan figürlerinde görülmektedir. Ayrıca yine sarayın buluntuları içerisinde yer alan lüster tekniğindeki siren/harpi tasvirinin (Öney 1967, fig. 11) karakteristik yüz tipinde olduğu dikkat çeker (Baer 2004, 13-15).
} 
figür daha Akdenizli bir görünüme sahip olan Kubadabad çinisindeki siren figürü ile çok benzer fenotiptedir" 37 ifadesini kullanmıştır.

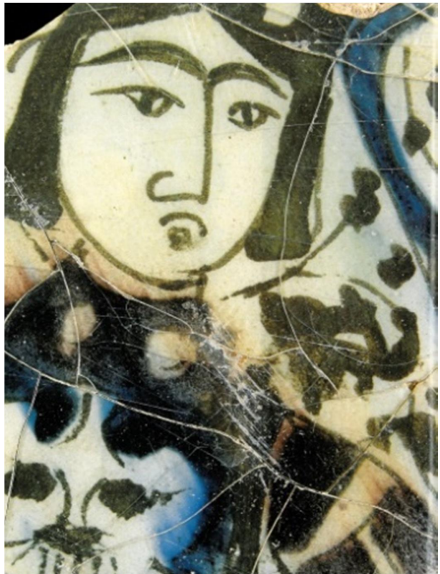

Figür 15b: Kubadabad Saray1 siren tasvirli çiniden detay (Arık 2000, fig. 162)

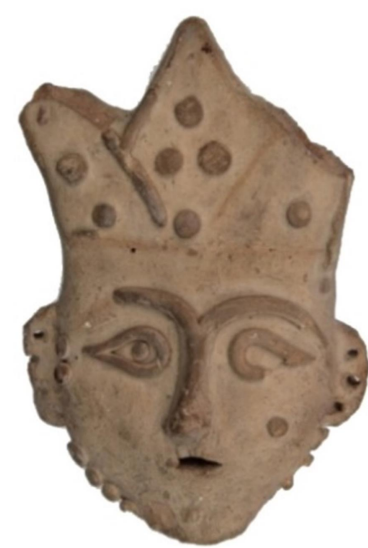

Figür 16: Barbutin tekniğindeki insan başı (Karatay Medresesi Çini Eserler Müzesi, env. no. 2604) (Karatay Medresesi Çini Eserler Müzesi Arşivi)

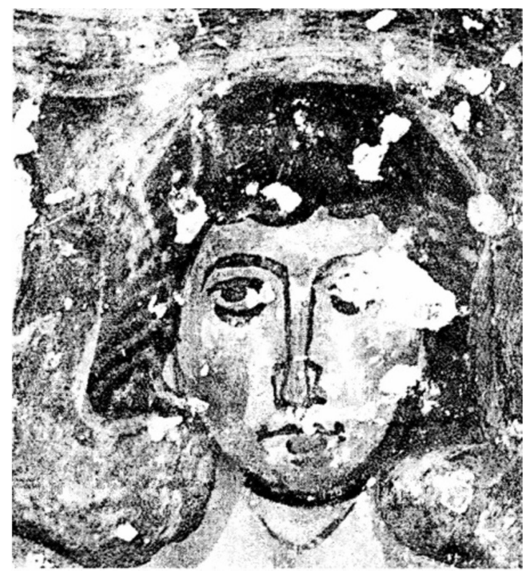

Figür 17: Suveş Sebastoslu Kırk Martyr Kilisesi'nin tonozundaki kadın figürü (Tekinalp 2006, fig. 4)

\section{Değerlendirme ve Sonuç}

Türklerin "tuğrul”, "zümrüd-ü anka", İranlıların "simurg" veya "sirenk", Arapların ise "'anka"' olarak adlandırdıkları, insan üstü kuvvetleri olduğuna inanılan, efsaneye göre Kafdağı'nda yaşayan, iyiliği simgeleyen, ihtiyacı olanlara yardım eden siren/harpi 38 tasvirleri İslam sanatında farklı eser türlerinde oldukça yaygın kullanılan bir motif olmuştur. Selçuklu sanatında siren, sfenks, grifon, kanatlı aslan ve melekler gibi doğa üstü güçleri olduğuna inanılan hayali yaratıklar saraylarda, kalelerde, kervansaray yapılarında, koruyucu olarak türbelerde, mezar kültü ve hayat ağacı sembolüyle ${ }^{39}$ birlikte yoğun bir şekilde tasvir edilmişlerdir ${ }^{40}$. E. Baer, İslam sanatında siren/harpi tasvirlerinin kökeninin Orta Asya ve Hindistan sanatı olabileceğini önermektedir ${ }^{41}$. Siren/harpi tasvirleri Orta Asya sanatında, Çin sanatında görülmekle birlikte Uygur ve Karahanlı dönemlerine ait İslam sanatı örnekleri de bulunmaktadır ${ }^{42}$. Mezopotamya ve Yunan kültüründe yer alan siren/harpi figürünün Anadolu Selçuklu sanatına Büyük Selçuklu sanatından geçtiği düşünülmektedir. Siren, Anadolu Selçuklu sanatında iyilik ve yardım sembolü olarak karşımıza çıkarken, Konya Kalesi'ndeki siren kabartmasına farklı bir simgesel anlam yüklenerek, adaletli Sultanı temsil ettiği düşünülmektedir ${ }^{43}$. Selçuklu figür sanatında sirenler "başlarında taçları kanat ve kuyruk uçlarında görülen ejder başlarn ile Avrasya hayvan üslubunu yansitırlar. Ölünün ruhunu koruyan ve hayat ağacını bekleyen bu yaratıklar Şaman kültü ile ilgili inanışları da aksettirirler"44. Şamana, yer altı ve gökyüzü seyahatinde refakat eden koruyucu ruhların kuş şeklinde efsanevi yaratıklar olduğu bilinmektedir ${ }^{45}$. L. Avşar, Selçuklu

\footnotetext{
37 Tekinalp 2006, 106.

38 Önder 1967a, 164; Ögel 2010, 108. anlatım sunmaktadır (Öney 1967, 153-154).

40 Öney 2008a, 417.

41 Baer 1965, 25-28.

42 Karasu ve Özkul-Findık 2019, 110.

43 Önder 1967a, 164.

44 Öney 2008a, 417

45 Öney 1967, 151.
}

${ }^{39}$ Kayseri Karatay Han taç kapısındaki soyut hayat ağacı ekseni altındaki siren çifti, hanı evrenin merkezi olarak belirleyen ve yolcuları koruyup uğur getirdiğine inanılan yaratıklardır. Niğde Hüdavend Hatun Türbesi kabartmalarında yer alan siren, sfenks (?) çift başlı kartal ve maske tasvirleri hayat ağacı kültü ile açıklanan bir 
siren/harpi motifinin "Ortak coğrafya veya ortak din çerçevesindeki karşılıklı etkileşim sonucu şekillenen pek çok motif gibi nispeten arkaik ve geç dönem anlam katmanların barındırdığını, kabaca bu katmanlan İslam öncesi Avrasya ve İslam Dönemi Yakın Doğu ve Anadolu coğrafyalarryla ilişkilendirmek ne kadar çekici gözükse de simgenin daha Türkistan'dan itibaren Budist, Hiristiyan ve Sasani etkileriyle harmanlandığını" 46 vurgular.

Son yıllarda Selçuklu sanatı ve arkeolojisiyle ilgili yapılan araştırmalar, Anadolu Selçuklu figür sanatının oldukça zengin olduğunu göstermiştir. İran Selçuklu sanatının bir devamı niteliğinde olan el sanatlarının yanı sıra mimaride de alçı ve taş kabartmalarda görülen bu zengin figür stili, Bizans sanatını da etkilemiştir. Anadolu' da benzer İslam figür tarzını geliştiren Anadolu Selçuklularının Bizans ile benzer ve çağdaş örnekler vermeleri, aynı ana kaynakların etkisiyle olmuştur ${ }^{47}$. Erken dönemlerden itibaren Bizans figür sanatında İslam sanatı etkilerinin görüldüğü bilinmektedir. Rice, bu etkileri özellikle İran'da, Sasani ve Erken İslam sanatına bağlayarak, Bizans seramik sanatında görülen, Mezopotamya ve İran'dan gelen Erken İslam dönemi etkilerini vurgular48. G. Öney ise "Bizans seramik, kumaş, metal işçiliğinde ve mermer kabartmalarında görülen çeşitli figürlerin bazıların konu stil bakımından kısmen İran Selçuklu ve özellikle Anadolu Selçuklu üslubuna" bağlar. "12. yüzyıldan sonra Bizans eserlerindeki İslam sanatı etkilerini kendilerine bölge ve temaslar bakımından çok daha yakın olan Anadolu Selçuklularna bağlamak gerektiği"49 görüşündedir.

9. yüzyıl ile 13. yüzyıl arasındaki dönemde, erken İslam ülkeleri ve Anadolu'da Selçuklu, Bizans, Gürcü, Ermeni, Haçlı yerleşim bölgelerinde çok sayıda bulunan sgraffito tekniğinde süslemeye sahip seramikleri bölgelendirmek ve tarihlendirmek oldukça zordur. Figürlü örnekler bu konuda belirleyici olurken, üslup özellikleri ipucu vermektedir ${ }^{50}$. S. Bilici,"Orta Çağ Bizans coğrafyasında yaygın olarak görülen açık sarı ya da açık yeşil kurşun sırlı ince sgraffito seramikler, 11. yüzyıl ortalarından 13. yüzyılın başlarnna kadar uzanan süreçte değerlendirilmektedir. Madalyon ve bantlar içerisinde spiral, sahte küfi yazı, palmet, rumi örgü ya da insan, hayvan gibi figüratif temalarn incelikli olarak işlendiği zarif bezemelerde, insan figürleri dışında kuvvetli İslami etkiler dikkati çeker. Bezemelerin kalitesi 12. yy. sonlarında bozulur. Geç 12. ve erken 13. yy. örneklerinde aceleci ve ayrıntısız bir işleniş görülür" ${ }^{\prime \prime}$ tespitinde bulunmuştur.

13. yüzyıla tarihlenen bazı insan figürlü sgraffito tekniğindeki Bizans seramikleri Anadolu Selçuklu sanatı etkisinde değerlendirilmektedir ${ }^{52}$. Anadolu coğrafyasında Orta Çağ sanatsal üretimlerinde özellikle seramik gibi dolaşımı kolay, taşınabilir ürünlerde Bizans ve Selçuklu kültürünün izlerini taşıyan benzer üslup ve ikonografide eserlerle karşılaşılmaktadır. Her iki kültürde de yaygın olarak tasvir edilen figürler içerisinde siren/harpi, sfenks, çift başlı tek gövdeli yaratıklar ve melekler gibi koruyucu, tılsımlı güçleri olduğuna inanılan fantastik yaratıklar dikkat çeker. R. Özgan'a göre; "Yerleşik düzene geçen ve birarada yaşamaya başlayan tüm insan topluluklarında, en eski çağlardan itibaren toplumda öne çıkan seçkin insanlar ve mahiyetindekiler politik propoganda amaçlı olarak doğanın güçlü, kuvvetli, çevik özelliklere sahip olağanüstü hayvanlarna benzetilmiş veya bu tür insanlar, çevresine hükmedebilmek için olağan dışı ve olağanüstü yaratıklan örnek almıştır"53.

\footnotetext{
46 Avşar 2012, 8.

47 Öney 1971, 103.

48 Rice 1939, 203-207, lev. 86-98; Rice 1965, 194-236.

49 Öney 1971, 91, 103.

50 Öney 2008b, 387.

51 Bilici 2010, 103. Bu tür seramiklerin örnekleri başta İstanbul, Batı Anadolu'da çeşitli merkezlerde yoğun olarak bulunmuş, Akdeniz'de ise Meydancıkkale, Sillyon, Antakya ve Al-Mina'da daha az örnekleri bulunmuştur (Bilici 2010, 104).

52 Öney 1971, 101-102, fig. 43-44, 47; Doğer 2016, 66.

53 Özgan 2020, 99.
} 
Sanat eserlerinin üretiminde bani-usta faktörü ile birlikte coğrafya, üretildiği koşullar ve beslendiği kaynak, üretimi şekillendiren en önemli unsurlar olmuştur. Bu nedenle benzer ihtiyaçları karşılamak üzere üretilen bir çok eserin, birbirine benzer hatta bazen her iki kültürden de izler taşıması olağan bir durumdur. Dönemin siyasi, ekonomik, sosyal ve dini ortamını yansıtan, aynı zamanda da alıcının beğenisine hitap edecek nitelikte üretilen bu eserlerde ortak konu, tasvir ve figür anlayışının nedeni, ortak bir beğeniye hitap etmesiyle de ilgili olmalıdır. Belki de aynı atölyelerde çalışan, aynı pazarlarda karşılaşan bu ustaların, daha çok beğenilen eserleri üretmesi hem ticari hem de estetik bir gereksinmenin sonucudur. Bu durum, aynı coğrafyada zorunlu olarak doğan, ancak zaman içerisinde birlikte yaşam koşullarına uyum sağlayan iki toplumun, ihtiyaçları doğrultusunda sanatsal zevklerinin de zamanla ortak bir anlayış içerisinde şekillendiğini gösterir.

Karatay Medresesi Çini Eserler Müzesi'ndeki 1254 envanter numaralı seramik eserde, gövdesi, ayakların verilişi, boyama stili ile Bizans Dönemi özelliklerini yansıtan siren/harpi figürünün yüzü5, üç dilimli tacı ve yukarıya doğru kıvrılarak sonlanan kuyruğu Kubadabad Sarayı ve Konya Kalesi siren/harpi örnekleri ile karşılaştırıldığında, Anadolu Selçuklu Dönemi özelliklerini yansıtır. Aynı zamanda siren/harpi tasviri gövdesinin, kuyruğunun kanatlarının verilişi açısından Divriği Kalesi ve Kubadabad Sarayı tavus kuşu tasvirleriyle de paralel özellikler taşıdığı görülmektedir. Selçuklu sirenlerinde tipik olan, sırttan yükselen ikinci kanat ${ }^{55}$ ve Türk tipi üç dilimli taç56 olarak adlandırılan üç sivri tepelikli tacın Anadolu Selçuklu sanatında kullanımı oldukça yaygındır ${ }^{57}$. Ancak, 1254 envanter numaralı eserdeki siren/harpi tasviri, yukarıya doğru kıvrılan kanatlardaki göz ve tüylerin verildiği ayrıntılı süslemeler ile ayakların kuş ayaklarından farklı biçimde betimlenişi açısından Selçuklu örneklerinden ayrılır. Siren/harpi figürünün kuyruk ve kanadındaki çizgisel süsleme, Anadolu'nun yerel üslubunda oldukça yaygin olarak kullanılan kazıma çizgilerle belirginleştirilen bezeme anlayışını yansıtır. Süsleme özellikleriyle ünik olan eserde, siren/harpi figürünün Hristiyan ikonografisinde ölümsüzlük ve cenneti sembolize eden tavus kuşu tarzında işlenişi açısından da Bizans sanatıyla ilişkili olduğu düşünülebilir. Karatay Çini Eserler Müzesi 3676 envanter numaralı eserdeki siren/harpi tasviri de gövdesi, boyun ve başın veriliş tarzı açısından Selçuklu figür geleneğinin etkisini yansıtırken, figürün göz, kaş ve burun gibi yüzdeki ayrıntılarıyla Bizans figürleri tarzında olduğu dikkat çeker.

\footnotetext{
54 Siren/harpi figürünün oval yüzlü, iri badem gözlü, ortada birleşmiş kemerli kaşları, küçük ağız ve küçük burunlu verilişi gibi özellikleriyle benzer bir örnek, Komana kenti kazı buluntusu sgraffito tekniğindeki seramikte yer alır (Karasu ve Özkul-Fındık 2019, 126, kat. 6). Komana buluntusu siren tasviri, Ahlat kazılarında bulunan 13. yüzyılın ikinci yarısına tarihlendirilen siren tasviri (Karamağaralı 1981, 71, 93, şek. 19) ile birlikte yüz tipi, yanaklardaki benler gibi özelliklerle 13.-14. yüzyıllara tarihlendirilen insan figürleriyle (Karamağaralı 2007, 152153) benzerlik göstermektedir (Karasu ve Özkul-Fındık 2019, 110).

55 Öney 1967, 146-147.

56 “Bu tip taçlar Moğolistan'da Kudirge Kaya resimlerinde (M.S. 5 yy.) tanrıça figürünün başında, Gazne Sarayı kabartmalarındaki siren, sfenks gibi efsanevi yaratıklarda, Palermo'daki Capella Paletina tavan süslemelerinde yer alan hükümdarların başında, İran Selçuklularnda özellikle seramiklerde hükümdar ve masal hayvanları tasvirlerinde görülmektedir" (Öney 1967, 143-144, dn. 2). Baer'e göre İslam sanatında siren/harpi ve sfenks figürleri çoğunlukla benzer dekoratif şemalarda tasvir edilmektedir. Siren/harpi tasvirlerinin başlarındaki taçlar, inci diademleri kolyeleri ve kanatların kıvrımlı olarak sonlaması gibi özellikler, sfenkslerde olduğu gibi İran sanatı mirasının bir parçasıdır (Baer 1965, 26).

57 Üç dilimli taç Anadolu'da, Konya İnce Minare Taş ve Ahşap Eserler Müzesi'nde bulunan 893 envanter numaralı korkuluk levhasındaki sfenks figürlerinde, yine aynı müzede bulunan Konya Alaaddin Köşkü'nden gelmiş olan 886 envanter numaralı alçı siren kabartmasında, Konya Kalesi'nden getirilen 883 ve 884 envanter numaralı melek kabartmalarında, Karatay Medresesi Çini Eserler Müzesi 2604 envanter numaralı barbutin tekniğindeki sırsız pişmiş toprak insan başında, Niğde Hüdavend Hatun Türbesi siren figürlerinde ve bitkisel süsleme arasında yer alan maske tipi başlarda (Öney 1967, 143-144, 146-147, fig. 1a-b, 2, 7a-c), Kayseri Karatay Han Taç Kapısı'nda (Öney 1968, 24-50) ve Kubadabad Sarayı'nda bulunan çini örneklerinde (Arık 2000, 121) görülmektedir.
} 
Sonuç olarak, farklı malzeme ve teknikteki örneklerle karşılaştırmalı olarak ele aldığımız Karatay Medresesi Çini Eserler Müzesi 1254 ve 3676 envanter numaralı siren/harpi tasvirli eserler, Anadolu Selçuklu sanatı etkisinde üretilen Bizans seramikleri olarak değerlendirilebilir. Eserler, Orta Çağ Anadolusu'nda hem Selçuklu hem de Bizans resim geleneğini iyi bilen Bizanslı bir ustanın üretimi olabileceği gibi Türk bir ustanın yerli bir alıcı için ürettiği, özel kullanıma yönelik bir eşya da olabilir. Eserlerin ana kompozisyonunu oluşturan siren/harpi figürünün güçlü, kuvvetli, koruyucu fantastik figürler olarak taşıdığı ikonografik anlam düşünüldüğünde, belki de saray erkanından biri için hediye gibi özel bir amaçla üretildikleri de düşünülebilir. Her iki kültür ve sanattan izler taşıyan eserler, Orta Çağ Anadolusu çoklu kültürel ortamının özgün bir yaratımı olarak değerlendirilmelidir.

\section{Figürlerin Listesi}

Figür 1a: Karatay Medresesi Çini Eserler Müzesi, siren/harpi tasvirli kase (env. no. 1254)

Figür 1b: Siren/harpi tasvirli kasenin çizimi

Figür 1c: Siren/harpi tasvirli kasenin iç yüzeyi

Figür 1d: Kasenin iç yüzeyinin çizimi

Figür 2: Kubadabad Sarayı siren tasvirli çini (Arık 2000, fig. 158)

Figür 3: Kubadabad Sarayı siren tasvirli çini (Karatay Medresesi Çini Eserler Müzesi)

Figür 4: Siren tasvirli taş eser (İnce Minare Taş ve Ahşap Eserler Müzesi)

Figür 5: Siren/harpi tasvirli tabak (Dumbarton Oaks Koleksiyonu, env. no: D.O.58.103) (Rice 1966, fig. 1)

Figür 6: Divriği Kale kazısında bulunan seramik parçası (Acara-Eser 2020, şek. 10b)

Figür 7a-b: Kabartmalı mermer levhanın ön ve arka cephesi (İnce Minare Taş ve Ahşap Eserler Müzesi, env. no. 893) (İnce Minare Taş ve Ahşap Eserler Müzesi Arşivi)

Figür 7c: Kabartmalı mermer levhada soldaki sfenks figürü (Ince Minare Taş ve Ahşap Eserler Müzesi Arşivi)

Figür 8: Divriği Kalesi'nde bulunan tavus kuşu bezemeli seramik parçası (Acara-Eser 2019, fig. 4)

Figür 9: Kubadabad Küçük Saray'da bulunan tavus kuşu tasvirli çini (Arık 2000, fig. 92)

Figür 10a: Karatay Medresesi Çini Eserler Müzesi siren/harpi tasvirli kase parçası (env. no. 3676)

Figür 10b: Siren/harpi tasvirli kase parçasının çizimi

Figür 10c: Kase parçasının iç yüzeyi

Figür 10d: Kase parçasının iç yüzeyinin çizimi

Figür 11: Su kuşu üzerinde siren/harpi ve balık tasvirli kase (Korinth Arkeoloji Müzesi, env. no. C-1931-005)

(Papanikola-Bakirtzi 1999, kat. 196)

Figür 12: Siren/harpi tasvirli buhurdan (Atina Bizans ve Hristiyan Eserleri Müzesi, env. no. T 125/BM)

(Papanikola-Bakirtzi 1999, kat. 8)

Figür 13: D. T. Rice'1n özel koleksiyonunda bulunan siren/harpi figürlü fragman (Öney 1971, fig. 28)

Figür 14: Konya Kılıçaslan Köşkü'nde bulunan siren figürlü alçı kabartma (Türk ve İslam Eserleri Müzesi, env. no. 2340-5) (Arık 2000, fig. 17)

Figür 15a: Kubadabad Küçük Saray'da bulunan siren tasvirli çini (Arık 2000, fig. 163)

Figür 15b: Kubadabad Sarayı siren tasvirli çiniden detay (Arık 2000, fig. 162)

Figür 16: Barbutin tekniğindeki insan başı (Karatay Medresesi Çini Eserler Müzesi, env. no. 2604) (Karatay

Medresesi Çini Eserler Müzesi Arşivi)

Figür 17: Suveş Sebastoslu Kırk Martyr Kilisesi'nin tonozundaki kadın figürü (Tekinalp 2006, fig. 4) 


\section{Bibliyografya}

Acara-Eser, M. (2019). Divriği Kale Kazısı Sırlı Seramiklerinden Kuş ve Balık Figürlü Örnekler. SDÜ Fen-Edebiyat Fakültesi Sosyal Bilimler Dergisi, 48, 41-68.

Acara-Eser, M. (2020). Divriği Kale Kazısı Sırlı Seramik Buluntuları: İlk Sonuçlar ve Yerel Üretim İzleri. Hacettepe Üniversitesi Edebiyat Fakültesi Dergisi, 37(1), 136-153.

Arık, R. (2000). Kubad Abad: Selçuklu Sarayı Çinileri. İstanbul: Türkiye İş Bankası Kültür Yayınları.

Arık, R. (2007). Anadolu Selçuklu Saraylarında Çini. R. Arık ve O. Arık (Eds.), Anadolu Toprağının Hazinesi: Çini, Selçuklu ve Beylikler Çağı Çinileri (ss. 219-399). İstanbul: Kale Grubu Kültür Yayınları.

Avşar, L. (2012). Kubadabad Çinilerindeki Harpi-Siren Figürünün İzini Sürerken. Akademik Bakış Dergisi, 31, 2-21.

Baer, E. (1965). Sphinixes and Harpies in Medieval Islamic Art: And Iconographical Study. Jerusalem: Israel Oriental Society.

Baer, E. (2004). The human figure in Islamic art: Inheritances and Islamic transformations. Costa Mesa: Mazda Publishers.

Bilici, S. (2010). Alanya Kalesi Kazılarında Bulunan Port Saint Symeon Seramikleri ve Ortaçağ'da Akdeniz Seramik Üslubu. M. Dündar, A. Yavaş ve A. O. Uysal (Eds.), XII. Ortaçağ-Türk Dönemi Kazıları ve Sanat Tarihi Sempozyumu, 15-17 Ekim 2008 (ss. 365-373). İzmir: Hürriyet Matbaas1.

Bryennios, N. (2008). Tarihin Özü (Çev. B. Umar). İstanbul: Arkeoloji ve Sanat Yayınları.

Demiriz, Y. (1970). Konya Müzesi'nde Özel Durumdaki Bir Kabartma Hakkında. Sanat Tarihi Yillığı 3, 221-230.

Dirimtekin, F. (1993). Selçukluların Anadolu'ya Yerleşmelerini ve Gelişmelerini Sağlayan İki Zafer. Malazgirt Armağanı (ss. 231-258). Ankara: Türk Tarih Kurumu.

Doğer, L. (2004). Bizans Dönemi Fantastik Kurgulu Betimleme Taşıyan Yeni Bir Seramik Obje. Sanat Tarihi Dergisi, 13(2), 79-98.

Doğer, L. (2016). İnsan Figürlü Bizans Sırlı Seramik Repertuvarına Yeni Bir Örnek. Sanat Tarihi Dergisi, 10, 57-76.

Erdemir, Y. (2009). İnce Minare Taş ve Ahşap Eserler Müzesi. Konya: Konya Valiliği İl Kültür ve Turizm Müdürlüğü.

Evans, H. C. ve Wixom, W. D. (1997). The Glory of Byzantium: Art and Culture of the Middle Byzantine Era, A.D. 843-1261. New York: The Metropolitan Museum of Art; Harry N. Abrams, Inc. distributor.

Grimal, P. (1997). Mitoloji Sözlüğü Yunan ve Roma (Çev. S. Tamgüç). İstanbul: Sosyal Yayınları. 
Impelluso, L. (2004). Nature and Its Symbols (Çev. S. Sartarelli). Los Angeles: J. Paul Getty Museum.

Karamağaralı, B. (1981). Ahlat'ta Bulunan Bir Çini Fırını. Yıllık Araştırmalar Dergisi, 3, 67-93.

Karamağaralı, N. (2007). Ahlat Sırlı Seramikleri. G. Öney ve Z. Çobanlı (Eds.). Anadolu'da Türk Devri Çini ve Seramik Sanatı (ss. 133-153). Ankara: T.C. Kültür ve Turizm Bakanlı̆̆1 Yayınları.

Karasu, Y. E. ve Özkul-Findık, N. (2019). Figured Ceramics Found at Komana (Tokat) Excavations. D. B. Erciyas ve M. Acara-Eser (Eds.), Komana Small Finds (ss. 103-130). İstanbul: Ege Yayınları.

Khoniates, N. (1995). "Historia" (Ionnes ve Manuel Komnenos Devirleri) (Çev. F. Işıltan). Ankara: Türk Tarih Kurumu.

Köroğlu, G. (2007). Glazed Pottery from Cyprus and the Hatay-C,ukurova Region in the Mersin-Yumuktepe Excavations. B. Böhlendorf-Arslan, A. O. Uysal ve J. Witte-Orr (Eds.) Çanak: Late Antique and Medieval Pottery and Tiles in Mediterranean Archaeological Contexts, Byzas 7. (ss. 441-456) İstanbul: Ege Yayınları.

Kundurac1, O. ve Mimiroğlu, M. (2011). Byzantine Stone Works in The Private Koyunoğlu City Museum of Konya Metropolitan Municipality. H. Öniz ve E. Aslan (Eds.), SOMA 2009: Proceedings of the XIIIth Symposium on Mediterranean Archaeology Selçuk University of Konya, Turkey, 23-24 April 2009. Oxford: Archaeopress.

Lilie, R. J. (2005). XII. Yüzyılda Bizans ve Türk Devletleri (Çev. Y. Ayönü). Tarih İncelemeleri Dergisi, 20(1), 197-209.

Mimiroğlu, İ. M. (2006) Konya'nın Bizans Mimarisi. İpek Yolu Konya Kitabı IX, 139-171.

Morgan, C. H. (1942). The Byzantine Pottery. Corinth XI. Cambridge: Harvard University Press.

Ocak, A. Y. (1991). Anadolu'nun Türkleşmesi ve İslamlaşması. TDV İslam Ansiklopedisi III (ss. 110-116). İstanbul: Türkiye Diyanet Vakfı Yayınları.

Ostrogorsky, G. (1999). Bizans Devleti Tarihi (Çev. F. Işıltan). Ankara: Türk Tarih Kurumu.

Ögel, B. (2010). Türk Mitolojisi I. Ankara: Türk Tarih Kurumu Basımevi.

Önder, M. (1967a). Konya Kal'ası ve Figürlü Eserleri. VI. Türk Tarih Kongresi Tebliğleri (ss. 145-169). Ankara: Türk Tarih Kurumu Basımevi.

Önder, M. (1967b). Kubâd-Âbâd Sarayı Harpi ve Simurg'ları. Türk Etnografya Dergisi, 10, 517.

Öney, G. (1967). Niğde Hüdavent Hatun Türbesi Figürlü Kabartmaları. Belleten, XXXI(122), 143-167.

Öney, G. (1968). Anadolu Selçuklu Sanatında Hayat Ağacı Motifi. Belleten, XXXII(125), 25-36.

Öney, G. (1971). Bizans Figürlerinde Anadolu Selçuklu Etkisi. Selçuklu Araştırmaları Dergisi, Malazgirt Zaferi Özel Sayısı 900. Yıl, III, 91-118. 
Öney, G. (2008a). Selçuklu Figür Dünyası. D. Kuban (Ed.), Selçuklu Çağında Anadolu Sanatı. (ss. 411-428). İstanbul: Yapı Kredi Yayınları.

Öney, G. (2008b). Selçuklu Seramik Sanatı. D. Kuban (Ed.), Selçuklu Çağında Anadolu Sanatı. (ss. 385-390). İstanbul: Yapı Kredi Yayınları.

Özgan, R. (2020). Antik Çağ'dan Günümüze Çift Başlı Kartal: Anlamı, Yorumu ve Propogandas1. Arkhaia Anatolika, 3, 98-125. https://doi.org/10.32949/arkhaia.2020.17

Özkul-Fındık, N. (2001). İznik Roma Tiyatrosu Kazı Buluntuları (1980-1995) Arasındaki Osmanlı Seramikleri. Ankara: Türk Tarih Kurumu.

Papanikola-Bakirtzi, D. (1999). Byzantine Glazed Ceramics. The Art of Sgraffito. Athens: Archaeological Receipts Fund.

Parman, E. (2002). Ortaçağ'da Bizans Döneminde Frigya (Phrygia) ve Bölge Müzelerindeki Bizans Taş Eserleri. Eskişehir: Anadolu Üniversitesi Yayınları.

Redford, S. (2001). "Port Saint Symeon Seramiği" Denilen Hatay ve Çukurova Bölgesi Seramiği. S. Alpaslan (Ed.). V. Ortaçă̆ ve Türk Dönemi Kazı ve Araştırmaları Sempozyumu, 1920 Nisan 2001 (ss. 485-490). Ankara: Hacettepe Üniversitesi.

Rice, D. T. (1939). Iranian Elements in Byzantine Art. J. Orbeli (Ed.) IIIe Congrés International d'Art et d'Archéologie Iraniens (ss. 203-207). Leningrad: Académie des sciences de Russie.

Rice, D. T. (1965). The Pottery in Byzantium and the Islamic World. Studies in İslamic Art and Architecture in Honour of Professor K. A. C. Creswell (ss. 194-236). Cairo: American University in Cairo Press.

Rice, D. T. (1966). Late Byzantine Pottery at Dumbarton Oaks. DOP, 20, 207-219. https://doi.org/10.2307/1291246

Savvídĩs, A. G. K. (1981). Byzantium in the Near East: Its Relations with the Seljuk Sultanate of Rum in Asia Minor The Armenians of Cilicia and the Mongols A.D. 1192-1237. Thessalonikē: Kentron Buzantinōn Ereunōn.

Sevim, A. (1993). Malazgirt Meydan Savaşı ve Sonuçları. Malazgirt Armağanı (ss. 219-230). Ankara: Türk Tarih Kurumu Yayınları.

Tekinalp, V. M. (2006). Anadolu Selçuklu Sanatında Bizans Sanatının İzleri. Hacettepe Üniversitesi Türkiyat Araştırmalan Dergisi, 4, 95-125.

Urfalı Mateos. (2000). Urfalı Mateos Vekayi-nâmesi (952-1136) ve Papaz Grigor'un Zeyli (1136-1162). (Çev. H. D. Andreasyan). Ankara: Türk Tarih Kurumu.

Yinanç, M. H. (1934). Türkiye Tarihi. Selçuklular Devri. 1. Cilt: Anadolu'nun Fethi. İstanbul: Akşam Matbaası. 